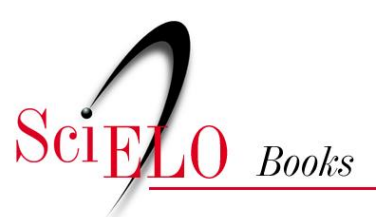

\title{
5. Morfologia dos ovos e ninfas
}

\author{
Dayse da Silva Rocha \\ Carolina Magalhães dos Santos
}

\section{SciELO Books / SciELO Livros / SciELO Libros}

ROCHA, DS., and SANTOS, CM. Morfologia dos ovos e ninfas. In: GALVÃO, C., org. Vetores da doença de chagas no Brasil [online]. Curitiba: Sociedade Brasileira de Zoologia, 2014, pp. 40-63.

Zoologia: guias e manuais de identificação series. ISBN 978-85-98203-09-6. Available from SciELO Books $<$ http://books.scielo.org $>$.

\section{(1) (1)(2)}

All the contents of this chapter, except where otherwise noted, is licensed under a Creative Commons Attribution-Non Commercial-ShareAlike 3.0 Unported.

Todo o conteúdo deste capítulo, exceto quando houver ressalva, é publicado sob a licença Creative Commons Atribuição Uso Não Comercial - Partilha nos Mesmos Termos 3.0 Não adaptada.

Todo el contenido de este capítulo, excepto donde se indique lo contrario, está bajo licencia de la licencia Creative Commons Reconocimento-NoComercial-CompartirIgual 3.0 Unported. 


\section{Morfologia dos ovos e ninfas}

(Dayse da Silva Rocha \& Carolina Magalhães dos Santos)

"... assim devemos nos aventurar no estudo de todos os tipos de animais sem hesitar, pois cada um e todos revelarão para nós algo natural e belo."

(Aristóteles, Partes dos Animais, I).
*Os desenhos esquemáticos utilizados neste capítulo foram reproduzidos de Lent \& Wygodzinsky (1979).

A importância do conhecimento dos ovos dos triatomíneos foi ressaltada por Pinto (1924) ao descrever a morfologia e a coloração dos ovos de Triatoma brasiliensis, conseguindo diferenciá-la de outras espécies de barbeiros existentes no Brasil. As primeiras descrições de estádios ninfais foram feitas por Pinto (1927) que destacou principalmente estruturas do rostro, inserção das antenas e morfologia do tórax e com isso elaborou uma chave para identificação dos gêneros de triatomíneos. Posteriormente, Galliard (1935) mostrou que o exócorio dos ovos dos triatomíneos têm em sua superfície externa uma arquitetura peculiar que permitiu a diferenciação entre as espécies Rhodnius prolixus, Triatoma vitticeps, T. dimidiata, T. rubrovaria e T. protracta. A partir daí, muitos autores passaram a dedicar mais atenção ao estudo destas estruturas. Foi o caso de Usinger (1944), que utilizou principalmente caracteres morfológicos e cromáticos das ninfas de $5^{\circ}$ estádio, para elaborar uma chave de identificação de alguns gêneros. Esta chave foi posteriormente ampliada com a inclusão das ninfas de $1^{\circ}$ estádio e publicada por Lent \& Wygodzinsky (1979).

Abalos \& Wygodzinsky (1951), ao estudarem ovos e ninfas dos triatomíneos da Argentina, observaram diferenças entre as espécies Psammolestes arthuri, Panstrongylus megistus, T. rubrofasciata, T. infestans, T. platensis, T. eratyrusiformis, T. sordida, T. guasayana, T. patagonica, T. rubrovaria e $T$. delpontei e, a partir daí, montaram uma chave dicotômica que possibilitava a identificação destas espécies por meio da ornamentação dos ovos.

Barata (1981) fundamentando-se nas características do exocorio e do opérculo dos ovos, mostrou ser possível empregar as estruturas e ornamentações como caracteres diagnósticos das espécies do gênero Rhodnius, preparando uma chave para identificação que incluiu dez espécies. Durante os anos seguintes, o estudo das ninfas limitou-se principalmente a descrições isoladas ou no máximo comparações entre duas espécies afins, até que Galíndez Girón et al. (1998) atualizaram a chave de gêneros publicada por Lent \& Wygodzinsky (1979) excluindo apenas o gênero Hermalentia em decorrência da indisponibilidade de espécimes para estudar.

A microscopia eletrônica de varredura (MEV) tem se mostrado uma importante ferramenta para uso na taxonomia, pois auxilia na observação e análise de novas estruturas. Particularmente no estudo das fases imaturas a utilização desta técnica vem se mostrando útil na diferenciação de espécies afins por permitir a observação de detalhes da anatomia externa dos triatomíneos que 
não podem ser vistos na microscopia convencional (Silva et al. 1999, 2002, 2003, 2005, 2010, Naegele et al. 2003). Barth \& Muth (1958), foram uns dos precursores na utilização da MEV, identificando nas ornamentações da superfície dos ovos caracteres diagnósticos para as espécies brasileiras de maior importância epidemiológica na época ( $P$. megistus, T. infestans, $T$. sordida, T. brasiliensis, $T$. vitticeps, $R$. prolixus e $R$. neglectus). Carcavallo et al. (1978), utilizaram MEV para estudar a morfologia dos triatomíneos e, desta forma, descreverem ninfas de $2^{\circ}, 3^{\circ}$ e $4^{\circ}$ estádios de Alberprosenia goyovargasi evidenciando estruturas diagnósticas na diferenciação entre os estádios imaturos. Lent \& Wygodzinsky (1979), também fizeram uso de MEV para o estudo da morfologia dos triatomíneos enfatizando algumas estruturas cuticulares, sulco estridulatório e tricobótrias. Esta ferramenta mostrou aplicações práticas com a publicação da chave de identificação das espécies do gênero Rhodnius baseada em caracteres dos ovos (Barata, 1981). A partir de então uma série de trabalhos utilizando tanto microscopia ótica quanto microscopia eletrônica de varredura vem sendo desenvolvidos por diversos autores (veja Tabela 5.1)

Recentemente, outra ferramenta foi incorporada aos estudos das formas imaturas de triatomíneos, a morfometria geométrica, que pode ser utilizada para os ovos (Páez-Colasante \& Aldana 2008, Gonzáles et al. 2009) ou para as ninfas (Rocha et al. 2005, Galvão et al. 2005, Patterson et al. 2009, Santos et al. 2009). Esta ferramenta visa traçar o perfil do desenvolvimento pós-embrionário de cada espécie, analisando desde o $1^{\circ}$ estádio até os adultos, ressaltando as deformações mais significativas ocorridas na forma durante o crescimento do triatomíneo.

Tabela 5.1 - Sumário dos trabalhos dedicados à morfologia de ovos e ninfas de triatomíneos encontrados na literatura no período de 1975 a 2010.

\begin{tabular}{llr}
\hline Espécies & Enfoque & Referência \\
\hline $\begin{array}{l}\text { Alberprosenia } \\
\text { goyovargasi }\end{array}$ & $\begin{array}{l}\text { Descrição das ninfas de } 2^{\circ}, 3^{\circ} \text { e } 4^{\circ} \text { estádios (MO)* e } \\
\text { visualização de estruturas por meio de MEV* }\end{array}$ & Carcavallo et al. 1978 \\
A. malheiroi & $\begin{array}{l}\text { Descrição dos ovos e ninfas (MO) e visualização } \\
\text { de estruturas por meio de MEV }\end{array}$ & Carcavallo et al. 1995 \\
Belminus herreri & Descrição (MO) e morfometria geométrica das ninfas \\
Cavernicola lenti & $\begin{array}{l}\text { Descrição dos ovos e ninfas (MO) e visualização } \\
\text { de estruturas por meio de MEV }\end{array}$ & Rocha et al. 2005 \\
Dipetalogaster maxima & $\begin{array}{l}\text { Descrição dos ovos e ninfas (MO) e visualização } \\
\text { de estruturas por meio de MEV } 1991\end{array}$ & Costa et al \\
Linshcosteus confumus & $\begin{array}{l}\text { Descrição dos ovos (MO) e visualização } \\
\text { de estruturas por meio de MEV }\end{array}$ & Jurberg et al. 1993 \\
L. costalis & $\begin{array}{l}\text { Descrição dos ovos (MO) e visualização } \\
\text { de estruturas por meio de MEV }\end{array}$ & Haridass 1986 \\
L. karupus & $\begin{array}{l}\text { Descrição dos ovos e ninfas (MO) e visualização } \\
\text { de estruturas por meio de MEV } \\
\text { Morfologia, morfometria e histologia dos ovos } \\
\text { Estudo do exocório de ovos eclodidos }\end{array}$ & Haridass 1986 \\
& & Galvão et al. 2005 \\
\end{tabular}




\begin{tabular}{|c|c|c|}
\hline Espécies & Enfoque & Referência \\
\hline M. phyllosomus & $\begin{array}{l}\text { Morfologia, morfometria e histologia dos ovos } \\
\text { Estudo do exocório de ovos eclodidos }\end{array}$ & $\begin{array}{r}\text { Obara et al. } 2007 \\
\text { González et al. } 2009\end{array}$ \\
\hline M. longipennis & $\begin{array}{l}\text { Morfologia, morfometria e histologia dos ovos } \\
\text { Estudo do exocório de ovos eclodidos }\end{array}$ & $\begin{array}{r}\text { Obara et al. } 2007 \\
\text { González et al. } 2009\end{array}$ \\
\hline M. pallidipennis & $\begin{array}{l}\text { Morfologia, morfometria e histologia dos ovos } \\
\text { Estudo do exocório de ovos eclodidos }\end{array}$ & $\begin{array}{r}\text { Obara et al. } 2007 \\
\text { González et al. } 2009\end{array}$ \\
\hline Mepraia spinolai & Morfologia e morfometria de pernas & Naegele et al. 2003 \\
\hline $\begin{array}{l}\text { Microtriatoma } \\
\text { trinidadensis }\end{array}$ & $\begin{array}{l}\text { Descrição dos ovos e ninfas (MO) } \\
\text { Descrição dos ovos e ninfas (MO) }\end{array}$ & $\begin{array}{l}\text { Carcavallo et al. } 1976 \\
\text { De la Riva et al. } 2001\end{array}$ \\
\hline Nesotriatoma flavida & Morfometria & Jiménez \& Fuentes 1981 \\
\hline (como T. flavida) & Estudo do exocório de ovos eclodidos & González et al. 2009 \\
\hline Panstrongylus megistus & $\begin{array}{l}\text { MO de estruturas abdominais de ninfas de } 5 \text { estádio } \\
\text { Diferenças no tamanho dos ovos } \\
\text { Morfometria e morfologia das antenas }\end{array}$ & $\begin{array}{r}\text { Rosa \& Barata } 1997 \\
\text { Rosa et al. } 2003 \\
\text { Rosa et al. } 2010\end{array}$ \\
\hline P. geniculatus & Descrição dos ovos e ninfas (MO) & Lent \& Jurberg 1969 \\
\hline Psammolestes arthuri & Descrição dos ovos e ninfas (MO) & Carcavallo et al. 1975 \\
\hline Rhodnius brethesi & $\begin{array}{l}\text { Morfometria dos ovos } \\
\text { Descrição dos ovos e ninfas (MO) }\end{array}$ & $\begin{array}{l}\text { Mascarenhas } 1982 \\
\text { Mascarenhas } 1987\end{array}$ \\
\hline R. colombiensis & Descrição comparativa dos ovos & Santos et al. 2009 \\
\hline R. milesi & Descrição comparativa dos ovos & Santos et al. 2009 \\
\hline R. neglectus & $\begin{array}{l}\text { MO de estruturas abdominais de ninfas de } 5^{\circ} \text { estádio } \\
\text { Morfometria geométrica da borda } \\
\text { corial e do colar dos ovos } \\
\text { Morfometria e morfologia das antenas }\end{array}$ & $\begin{array}{r}\text { Rosa \& Barata } 1997 \\
\text { Paéz-Colasante \& } \\
\text { Aldana } 2008 \\
\text { Rosa et al. } 2010\end{array}$ \\
\hline R. neivai & $\begin{array}{l}\text { Descrição dos ovos e ninfas (MO) } \\
\text { Morfometria geométrica da borda } \\
\text { corial e do colar dos ovos }\end{array}$ & $\begin{array}{r}\text { Lent \& Valderrama } 1977 \\
\text { Paéz-Colasante \& } \\
\text { Aldana } 2008\end{array}$ \\
\hline R. nasutus & $\begin{array}{l}\text { Morfometria geométrica da borda } \\
\text { corial e do colar dos ovos }\end{array}$ & $\begin{array}{r}\text { Paéz-Colasante \& } \\
\text { Aldana } 2008\end{array}$ \\
\hline R. pallescens & Descrição dos ovos e ninfas (MO) & Jurberg \& Rangel 1980 \\
\hline R. pictipes & Descrição dos ovos e ninfas (MO) & Lent \& Valderrama 1977 \\
\hline R. prolixus & $\begin{array}{l}\text { Descrição dos ovos e ninfas (MO) } \\
\text { Geometria do exocório das células dos ovos } \\
\text { Morfometria geométrica da borda } \\
\text { corial e do colar dos ovos } \\
\text { Morfometria e morfologia das antenas }\end{array}$ & $\begin{array}{r}\text { Lent \& Valderrama } 1977 \\
\text { Chaves \& Añez } 2003 \\
\text { Paéz-Colasante \& } \\
\text { Aldana } 2008 \\
\text { Rosa et al. } 2010\end{array}$ \\
\hline R. robustus & $\begin{array}{l}\text { Morfometria geométrica da borda } \\
\text { corial e do colar dos ovos }\end{array}$ & $\begin{array}{r}\text { Paéz-Colasante \& } \\
\text { Aldana } 2008\end{array}$ \\
\hline R. stali & Descrição comparativa dos ovos & Santos et al. 2009 \\
\hline Triatoma arthurneivai & Morfologia do tórax das ninfas & Rosa et al. 2005 \\
\hline
\end{tabular}




\section{Espécies}

T. barberi

T. baratai

T. brasiliensis

T. breyeri

T. circummaculata

T. costalimai

T. deaneorum (como T. deanei)

T. delpontei

T. dimidiata

T. infestans

T. guasayana

T. guazu

T. jurbergi

T. klugi

T. lecticularia

T. lenti

T. maculata

\section{Enfoque}

Referência

Análise morfológica dos ovos

Descrição de ovos e ninfas por meio de MO e MEV

Descrição dos ovos (MO) e visualização de algumas estruturas por meio de MEV

MO de estruturas abdominais de ninfas de 5 estádio

Descrição e chaves para todos os estádios.

Estudo morfológico e histológico dos ovos

Morfologia da cabeça de ninfas de $1^{\circ}$ e $5^{\circ}$ estádio

Morfometria dos ovos, visualização de

algumas estruturas em MEV

Estudo morfológico e histológico dos ovos

Descrição dos ovos e ninfas (MO)

Martínez et al. 2010

Rocha et al. 2009

Jurberg et al. 1986

Rosa \& Barata 1997

Brewer \& Garay 1989

Obara et al. 2007

Rosa et al. 1999

Rosa et al. 2000a

Obara et al. 2007.

Galvão \& Fuentes, 1971

Morfometria

Descrição e chaves para todos os estádios.

Estudo morfológico de ovos e ninfas por MO e MEV

Descrição dos ovos e ninfas (MO)

Morfometria

Estruturas abdominais de ninfas de 5 estádio

Descrição e chaves para todos os estádios

Estudo do exocório de ovos eclodidos

Descrição e chaves para todos os estádios

Estudo da placa apical por meio de MEV

Análise das antenas por meio de MEV

Estudo comparativo do sulco

estridulatório, búcula e rostro

Brewer et al. 1983a

Brewer et al. 1983b

Mello et al. 2009

Brewer et al. 1981

Brewer et al. 1983a

Rosa \& Barata 1997

Brewer \& Garay 1989

González et al. 2009

Brewer \& Garay 1989

Silva et al. 1999

Silva et al. 2002

Silva et al., 2003

Silva et al. 1999

Estudo da placa apical por meio de MEV

Descrição dos ovos e ninfas (MO), visualização

de estruturas por meio de MEV

Análise das antenas por meio de MEV

Análise do sulco estridulatório, búcula

e rostro por meio de MEV

Estudo comparativo do sulco

estridulatório, bucula e rostro

Jurberg et al. 2002

Silva et al. 2002

Silva et al. 2003

Silva et al. 2010

Rocha et al. 1996

Descrição dos ovos e ninfas (MO) e visualização

de algumas estruturas por meio de MEV

Estudo do exocório de ovos eclodidos

González et al. 2009

Descrição dos ovos (MO) e visualização de

algumas estruturas por meio de MEV

Estudo do exocório de ovos eclodidos
Gonçalves et al. 1985

González et al. 2009 


\section{Espécies}

T. matogrossensis

T. melanosoma

(sinonímia de

T. infestans)

T. nitida

T. platensis

T. pseudomaculata

T. rubrofasciata

T. rubrovaria

T. sherlocki

T. sordida

T. tibiamaculata

T. vandae

T. vitticeps

T. williami

Ninfas de diversas espécies

Ovos de diversas espécies
Enfoque

Referência

Descrição dos ovos (MO) e visualização de

algumas estruturas por meio de MEV

Estruturas abdominais de ninfas de $5^{\circ}$ estádio

Estudo morfológico e histológico dos ovos

Descrição dos ovos (MO) e visualização de algumas

estruturas por meio de MEV

Descrição dos ovos (MO) e visualização de algumas estruturas por meio de MEV

Morfometria

Descrição e chaves para todos os estádios de três espécies.

Descrição e chaves para todos os

estádios de cinco espécies.

Descrição dos ovos (MO) e visualização de algumas

estruturas por meio de MEV

Descrição dos ovos (MO) e visualização de algumas

estruturas por meio de MEV

Morfologia da cabeça de ninfas de $1^{\circ}$ e $5^{\circ}$ estádios

Morfometria de ovos e visualização de algumas estruturas por meio de MEV

Morfometria das antenas

Estudo morfológico e histológico dos ovos

Morfometria

Descrição e chaves para todos os estádios de três espécies.

Descrição e chaves para todos os

estádios de cinco espécies.

Estudo do exocório de ovos eclodidos

Estruturas abdominais de ninfas de 5 estádio

Estudo morfológico e histológico dos ovos

Estudo morfológico comparativo de ovos

e ninfas por meio de MO e MEV

Estudo comparativo do sulco stridulatório, bucula e rostro

Descrição dos ovos (MO) e visualização de

algumas estruturas por meio de MEV

Morfometria e morfologia das antenas

Jurberg \& Campos 1995

Rosa et al. 2010

Galvão \& Fuentes 1971

Estudo morfológico comparativo de ovos

e ninfas por meio de MO e MEV

Estudo morfológico e histológico dos ovos

Estudo comparativo do sulco

estridulatório, bucula e rostro

Silva et al. 2005

Obara et al. 2007

Silva et al. 2010

Algumas estruturas de 66 espécies por meio de MO e MEV

Galíndez-Girón et al. 1998

Alguns aspectos estruturais vistos por meio de MO e MEV

* MO = microscopia ótica; MEV= microscopia eletrônica de varredura 


\section{Morfologia dos ovos}

Os ovos dos triatomíneos são formados pelo corpo do ovo e opérculo (Figura 5.1) que podem apresentar as mais diversas ornamentações

Existe uma grande variabilidade no tamanho e forma dos ovos dos triatomíneos, que podem ter menos de $1 \mathrm{~mm}$ de comprimento em Alberprosenia malheiroi até mais de $4 \mathrm{~mm}$ em Dipetalogaster maxima. As formas podem variar do cilíndrico como em Psammolestes arthuri, (Figura 5.2) a quase esféricos como em Panstrongylus rufotuberculatus.

A presença, ausência ou a forma das estruturas encontradas nos ovos como "colo" (Figura 5.3), "chanfradura lateral" e "colarinho" (Figura 5.4) podem auxiliar no reconhecimento de gêneros e espécies. Aspectos microscópicos também sofrem significativa variabilidade na sua estrutura. Como ausência e presença de "linhas limitantes" (Figura 5.5), ou existência ou não de estruturas nas "células hexagonais" (Figura 5.6).

Dentro do ovo se produz uma ecdise ao atingir a maturação do embrião, deixando uma "exúvia" após a emergência da ninfa de $1^{\circ}$ estádio (Galindez-Girón et al. 1998).

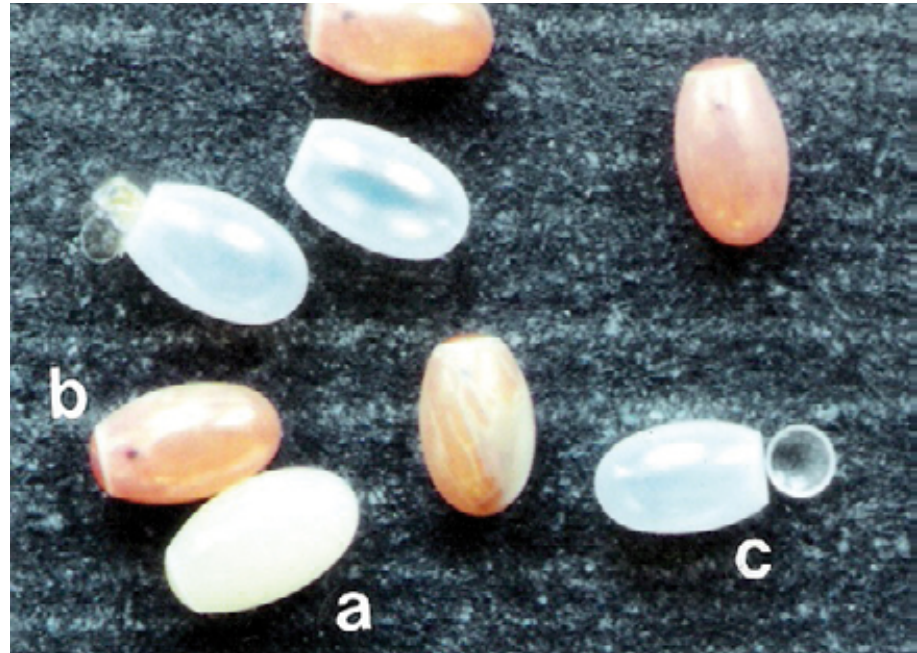

Figura 5.1: Ovos de triatomíneos, a: ovo recém posto, b: ovo embrionado, c: ovo eclodido e opérculo

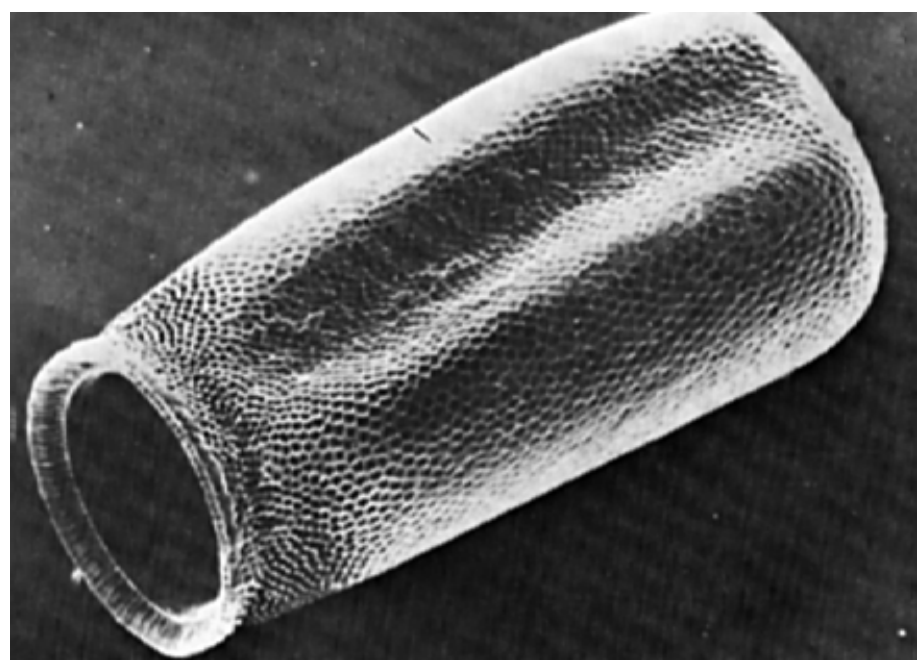

Figura 5.2: Ovo de Psammolestes arthuri visto através de microscopia eletrônica de varredura (reproduzido de Carcavallo et al. 1998)

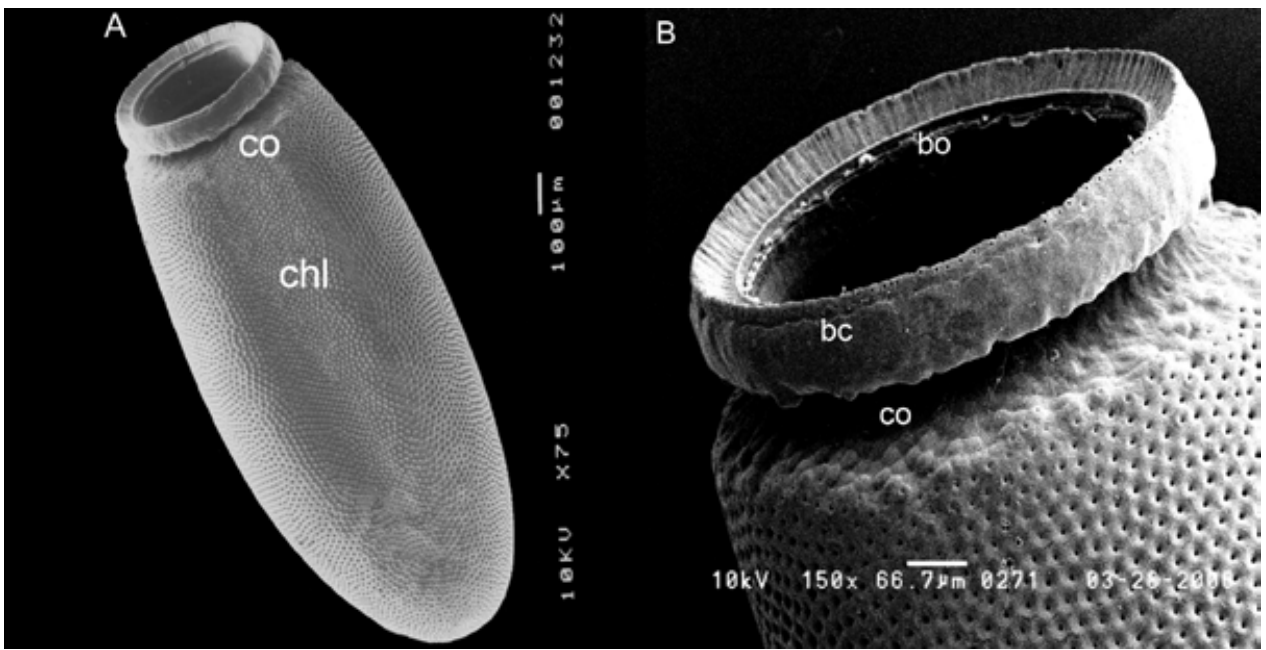

Figura 5.3: Ovo de Rhodnius visto através de microscopia eletrônica de varredura mostrando o colo (co), chanfradura lateral (chl), borda do opérculo (bo) e borda corial (bc)

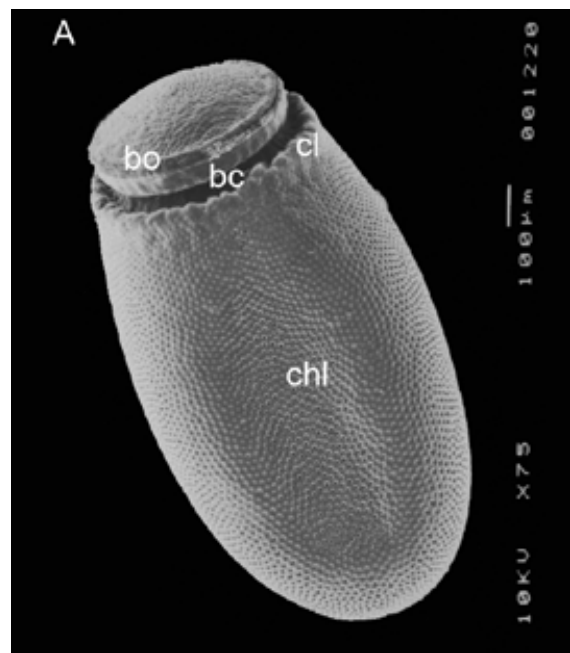

Figura 5.4: Ovo de Rhodnius visto através de microscopia eletrônica de varredura mostrando o colarinho (cl) 


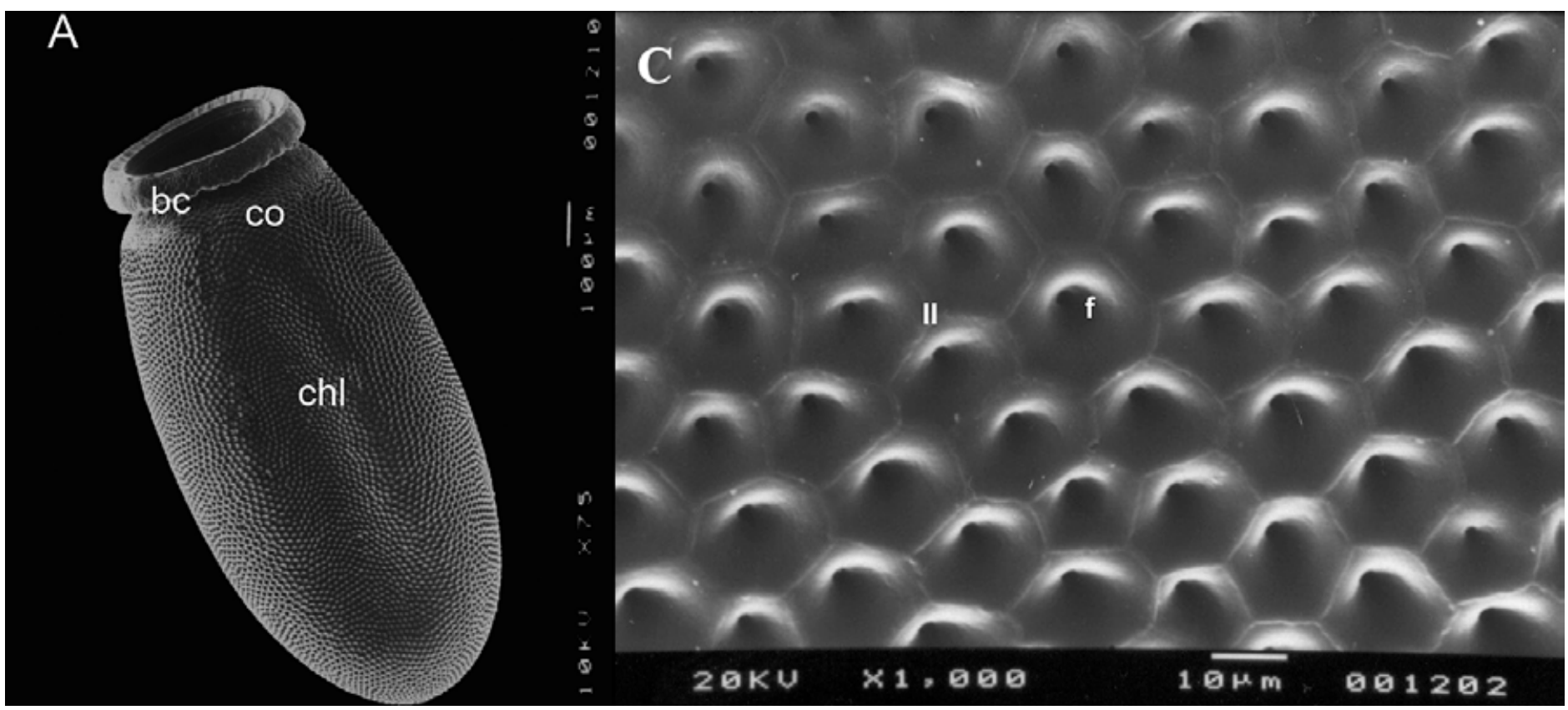

Figura 5.5: Ovo de Rhodnius visto através de microscopia eletrônica de varredura mostrando as linhas limitantes (II) e funil (f).

\section{Principais características dos ovos de Rhodnius, Triatoma e Panstrongylus}

No gênero Rhodnius as espécies põem os ovos aderidos ao substrato. $\mathrm{O}$ tamanho médio é de 1,72 mm de comprimento e $0,89 \mathrm{~mm}$ de diâmetro. $\mathrm{O}$ formato geral é elipsoide e acentuadamente assimétrico, com a presença de "chanfradura lateral" discreto em algumas espécies e muito evidente em outras. Todas as espécies possuem "colo" e "borda corial" evidentes. Cascas pouco translúcidas mas com fácil visualização da coloração do embrião, textura consistente, fosca, mas com discreto brilho sedoso, coloração variando entre o amarelo pálido ao castanho (Figura 5.3, 5.4, 5.5 e 5.7).

Em Triatoma os ovos são postos livres na maioria das espécies. O tamanho médio é de $2,05 \mathrm{~mm}$ de comprimento e 1,14 mm de diâmetro. O formato geral é elipsoide, podendo em algumas espécies ser mais alongado, são frequentemente
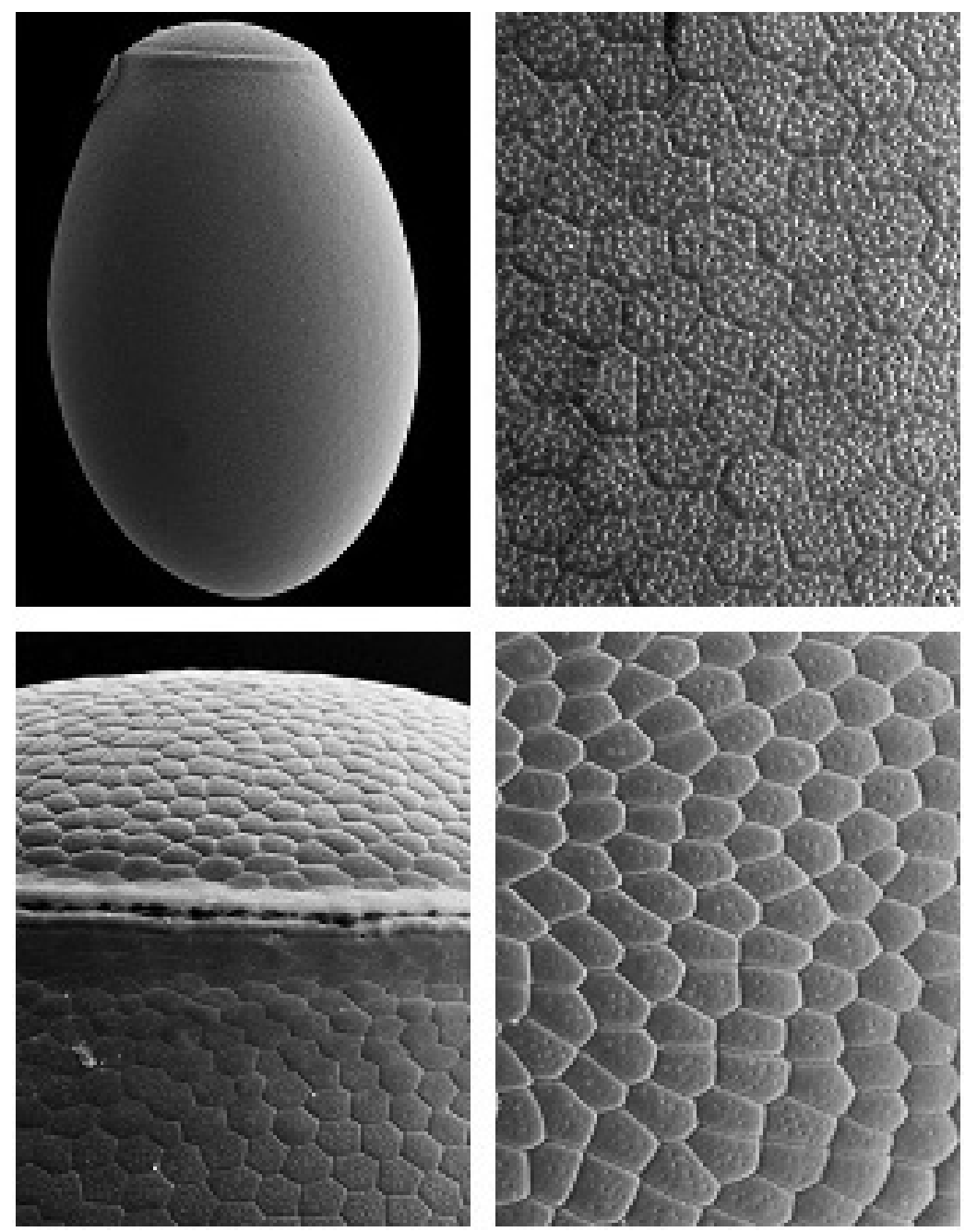

Figura 5.6: Ovo de Triatoma visto através de microscopia eletrônica de varredura mostrando as células do exocório 
simétricos e sem chanfradura lateral evidente. A maioria das espécies não apresenta "colo". As cascas são pouco translúcidas e a coloração varia do branco leitoso ao creme claro e permitem passar a coloração alaranjada do embrião maduro (Figuras 5.6 e 5.8).

Em Panstrongylus os ovos são postos livres. São grandes com média de 1,81 mm de comprimento e 1,30 mm de diâmetro. O formato pode variar do elipsoide ao mais arredondado quase globoso. São simétricos com ausência de "achatamento lateral", "colo" ou "colarinho". As cascas em todas as espécies são muito translúcidas, com textura firme brilhante, aparentemente delicada, de coloração branco perolada (Figura 5.9).

\section{Diferenças entre ninfas e adultos}

Da eclosão do ovo até chegar à fase adulta os triatomíneos passam por cinco estádios chamados de ninfas que podem ser diferenciadas dos adultos por apresentarem olhos menores, ausência de ocelos, ausência de asas, ausência de fossetas esponjosas (exceto nos gêneros Parabelminus e Microtriatoma) e pela imaturidade sexual. As ninfas de $4^{\circ}$ e $5^{\circ}$ estádios apresentam tecas alares, que são um "esboço" das futuras asas dos adultos, o pronoto tem forma de escudo, os tarsos são bissegmentados e a esclerotização do abdômen é incompleta (Lent \& Wygodzinsky 1979, Galíndez Girón et al. 1998, Aldana et al. 2000). No $5^{\circ}$ estádio podem apresentar diferenciação sexual externa e interna (Lent \& Jurberg 1965). No primeiro estádio apresentam uma coloração mais clara, e não apresentam manchas conexivais, mas, à medida que vão mudando para os estádios subsequentes, além de aumentarem de tamanho, estas manchas do conexivo se tornam aparentes, a quitinização se torna mais forte, acentuando a coloração. A partir do $3^{\circ}$ estádio começa a surgir o esboço do que será a teca alar, facilmente observada no $5^{\circ}$ estádio.

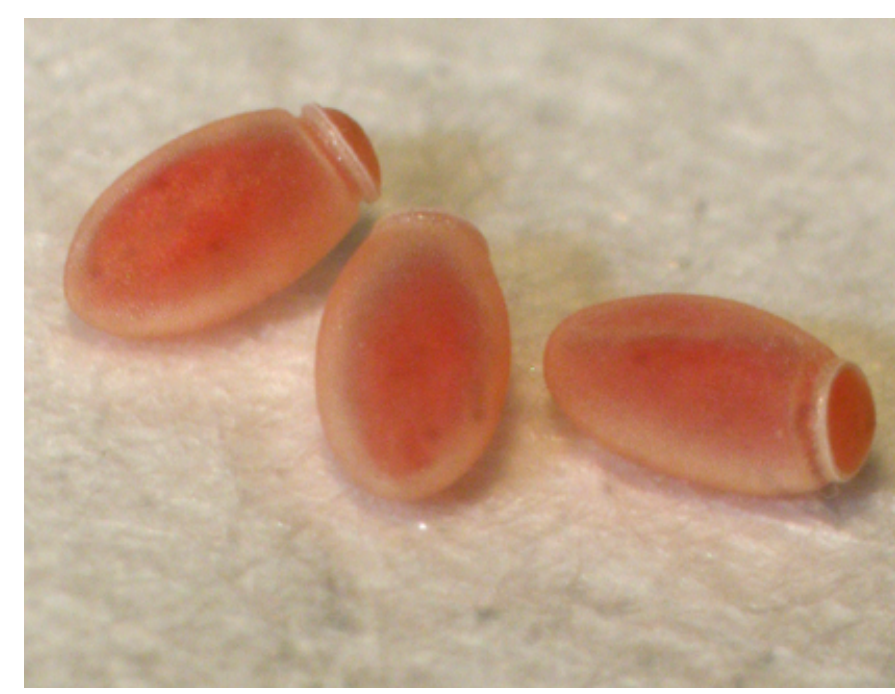

Figura 5.7: Ovos de Rhodnius aderidos ao substrato

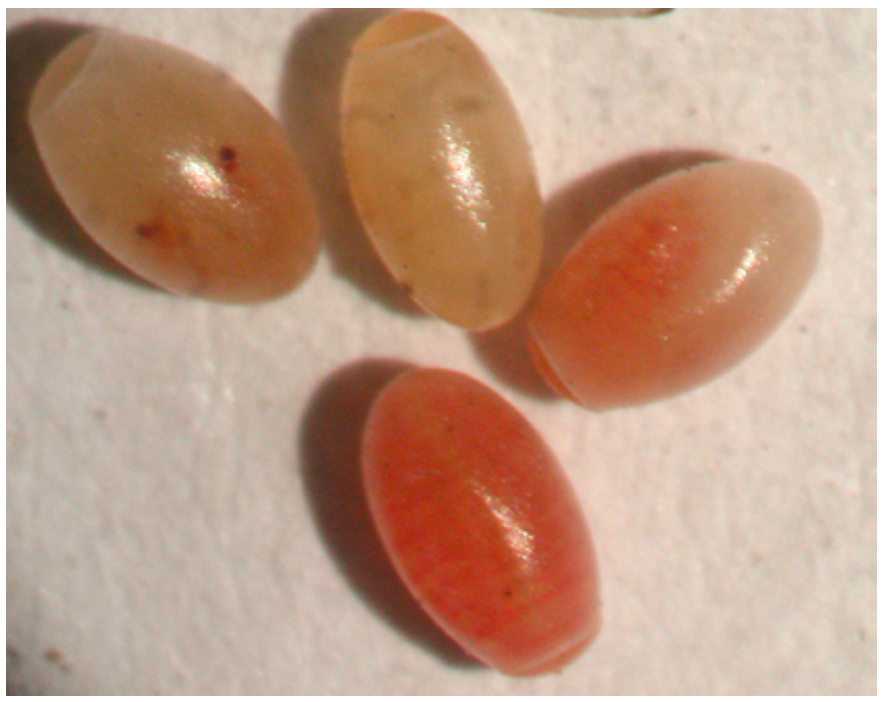

Figura 5.8: Ovos de Triatoma livres no substrato

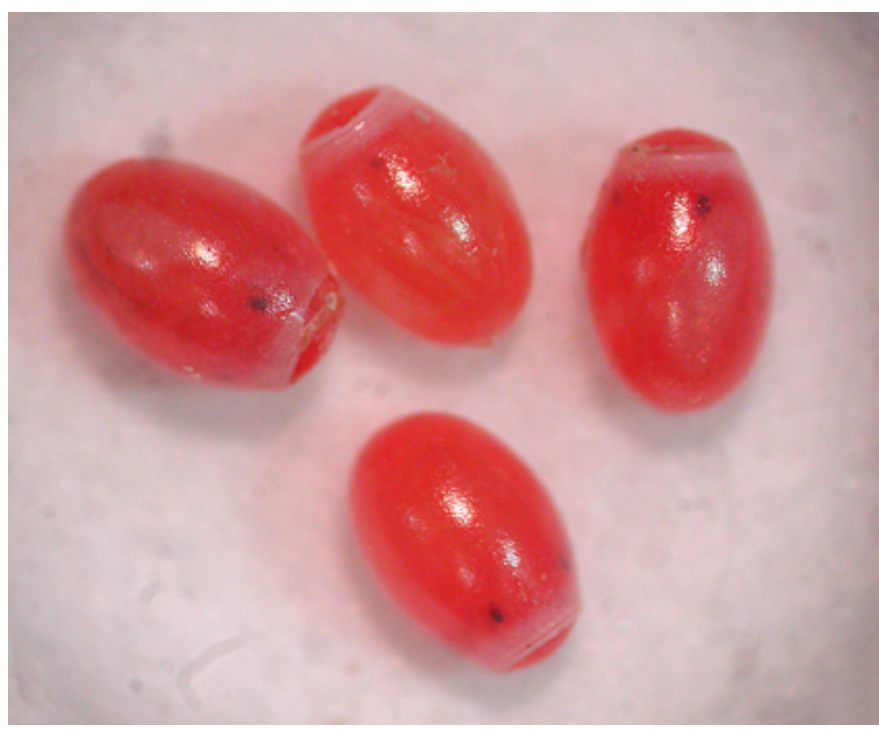

Figura 5.9: Ovos de Panstrongylus livres no substrato 


\section{Principais características para diferenciação entre os diferentes estádios ninfais:}

Primeiro estádio - Ninfas pequenas, com ausência total de manchas conexivais (Figura 5.10)

Segundo estádio - As ninfas são muito semelhantes morfologicamente as do primeiro estádio, exceto pelo aumento do comprimento do corpo que não é acompanhado na mesma proporção pelo crescimento da cabeça, ou seja, a cabeça das ninfas de $2^{\circ}$ estádio permanece quase do mesmo tamanho das de $1^{\circ}$ estádio. No primeiro e segundo estádios a margem posterior do mesotórax é reta ou arredondada posteriormente (Figura 5.11).

Terceiro estádio - As ninfas de terceiro estádio, apresentam o esboço das futuras tecas alares (Figura 5.12).

Quarto estádio - As tecas alares mesotorácicas ficam mais aparentes e cobrem as tecas alares metatorácicas (Figura 5.13).

Quinto estádio - As tecas alares são muito alongadas, as mesotorácicas cobrem completamente as metatorácicas (Figura 5.14).

A descrição dos ovos e ninfas é usada na tentativa de identificação das espécies de triatomíneos. Entretanto, a construção de uma chave completa para identificação de todas espécies em todas as suas fases imaturas é ainda um grande desafio, uma vez que menos de $30 \%$ das espécies conhecidas tiveram suas formas imaturas descritas. Destas, a maior parte ainda não foi analisada do ponto de vista da morfologia comparada o que tem inviabilizado até o momento a construção de uma chave específica que permita identificar por meio das formas imaturas todas as espécies conhecidas de triatomíneos. A seguir reproduzimos as chaves para formas imaturas publicadas na literatura até hoje.

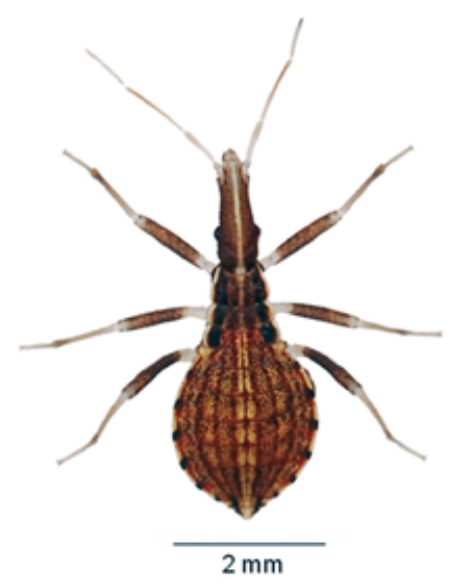

Figura 5.11: Ninfa de $2^{\circ}$ estádio de Rhodnius sp.

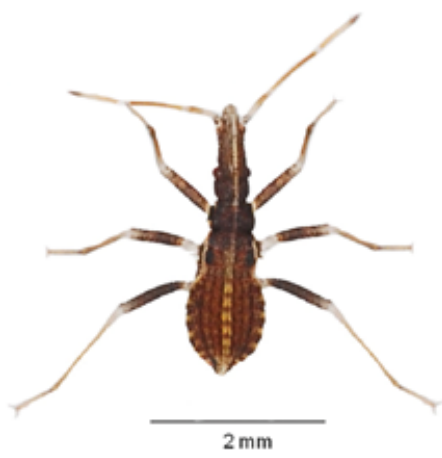

Figura 5.10: Ninfa de $1^{\circ}$ estádio de Rhodnius sp.

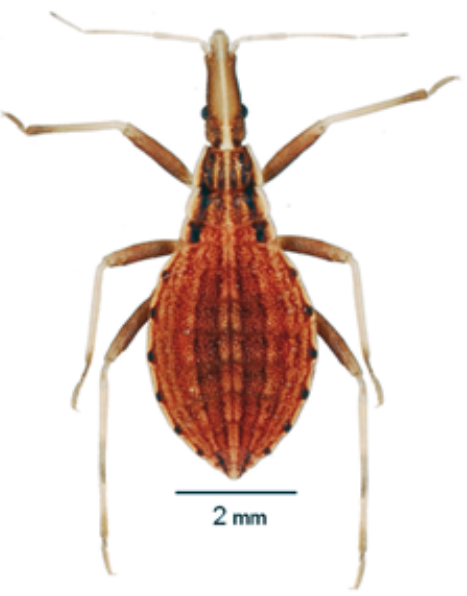

Figura 5.12: Ninfa de $3^{\circ}$ estádio de Rhodnius sp.

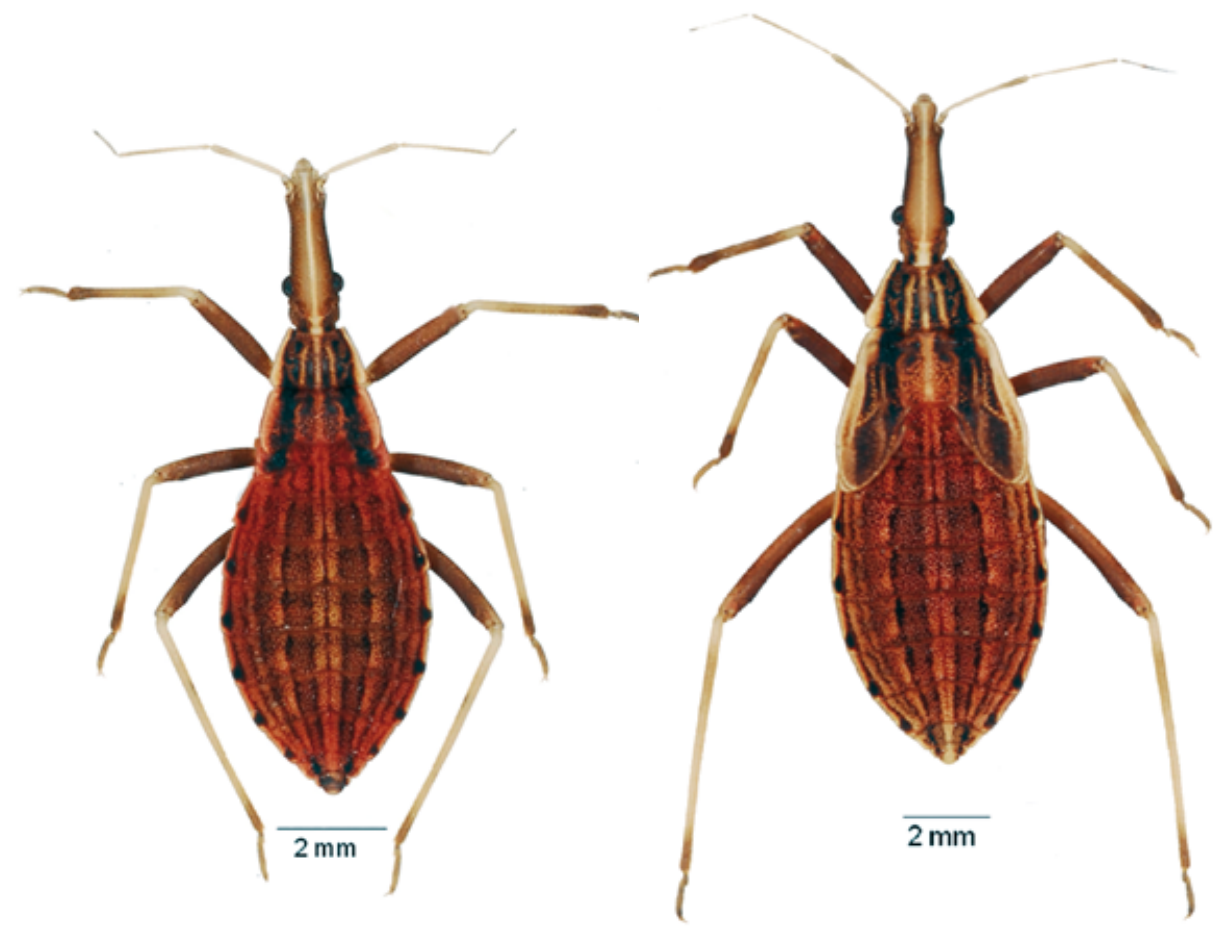

Figura 5.13: Ninfa de $4^{\circ}$ estádio de Rhodnius sp.
Figura 5.14: Ninfa de $5^{\circ}$ estádio de Rhodnius sp. 


\section{Chave para ninfas das espécies brasileiras mais comuns (segundo Galvão, 1956)}

1- Cabeça achatada e truncada na frente; antenas inseridas perto do ápice da cabeça; pernas salpicadas. Psammolestes coreodes

Cabeça subcilíndrica, os lados convergentes para adiante; inserção das antenas distante do ápice da cabeça, pernas de cor uniforme ou aneladas.

2- Cabeça relativamente curta; no aspecto dorsal, seu comprimento menor ou igual à largura máxima do pronoto; de perfil, com notável reentrância dorsal ao nível dos tubérculos anteníferos. Gênero Panstrongylus.

Cabeça mais comprida, fusiforme; no aspecto dorsal, seu comprimento maior que a largura máxima do pronoto; de perfil, sem tal reentrância dorsal. Gênero Triatoma.

3- Pernas negras: os grandes tubérculos discais da região anterior do pronoto e dos tergitos abdominais, muito evidentes.

P. megistus

Pernas castanho claras; os grandes tubérculos discais da parte anterior do pronoto e dos tergitos abdominais não evidentes.

P. geniculatus

4- Fêmures anelados; desenhos definidos no pronoto.............................................................................

Fêmures e tíbias sem anéis; sem desenhos definidos no pronoto.......................................................8

5- Fêmures com anel mediano largo e outro apical estreito.

Fêmures sem anel mediano, um único anel apical estreito; tíbias totalmente escuras; desenhos do pronoto com aspecto de duas interrogações.

T. maculata

6- Tíbias totalmente escuras; rostro delgado, afilando-se para o ápice, sem pelos longos no segundo e terceiro segmentos.

T. sordida

Tíbias com anel claro; rostro grosso com pelos longos no segundo e terceiro segmentos. .7

7- Tíbias com anel subasal; desenhos do pronoto com aspecto de duas interrogações; superfície dorsal do abdômen sem desenho definido.

T. infestans

Tíbias com anel subapical; desenho do pronoto com aspecto de dois oitos; superfície dorsal do abdômen com manchas claras e escuras em xadrez T. brasiliensis

8- Cabeça com faixa clara longitudinal; rostro grosso, com pelos longos no segundo e terceiro segmentos

T. vitticeps

Cabeça sem tal faixa; rostro delgado, afilando-se para o ápice, sem longos pelos no segundo e terceiro segmentos

9- Cabeça relativamente curta; pronoto negro, com bordos laterais de cor vermelha, estes sem vestígio de saliência tuberculiforme. T. rubrofasciata Cabeça muito alongada; pronoto, partes laterais e centrais dos segmentos abdominais com marcações vermelhas.

T. rubrovaria 


\section{Chave para os gêneros de triatomíneos (excluindo Bolbodera), baseada em ninfas de primeiro estádio (segundo Lent \& Wygodzinsky, 1979)}

1. Quarto artículo antenal mais longo que o primeiro, segundo e terceiro juntos; mesonoto em forma de estreita faixa transversal, mais curto que a metade do comprimento do pronoto; superfície do corpo, antenas e pernas com pelos simples muito longos, eretos ou decumbentes; fêmures com tricobótrias Cavernicola

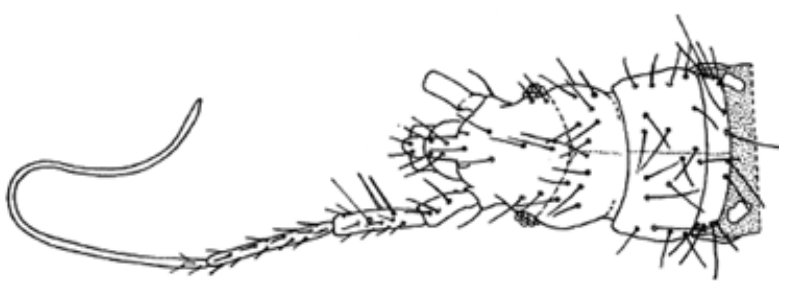

Quarto artículo antenal mais curto que o primeiro, segundo e terceiro juntos; mesonoto mais longo na linha mediana do que dos lados e não mais curto que a metade do comprimento do pronoto; superfície do corpo, na maioria dos casos, somente com pelos curtos, sendo alguns espinhosos, quando alongados se mostram invariavelmente espinhosos; fêmures sem tricobótrias...... 2
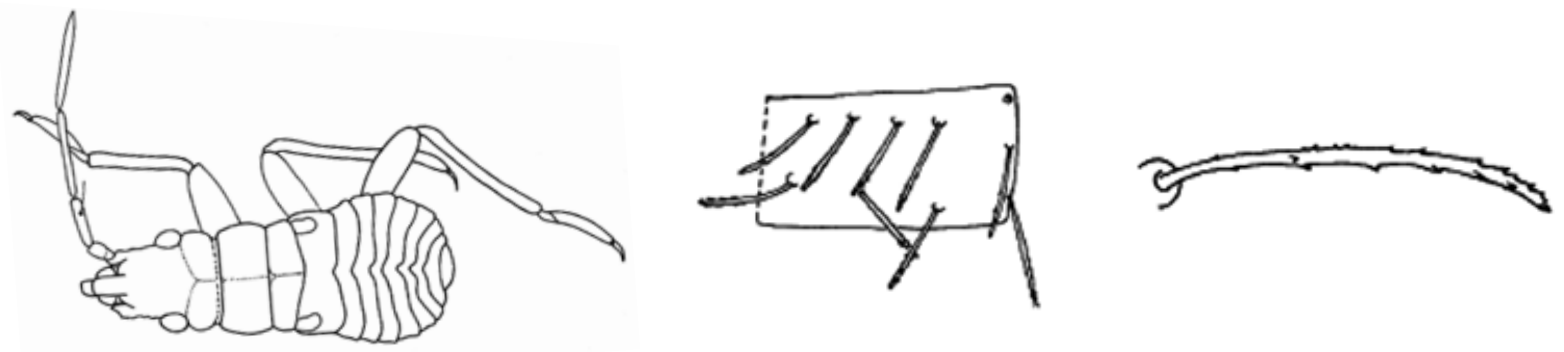

2. Fossetas esponjosas presentes nos três pares de pernas.

Parabelminus; Microtriatoma

Fossetas esponjosas ausentes.

3. Cabeça, tórax e pernas pintadas de claro e escuro, mosqueados; cerdas dos urotergitos muito curtas e irregularmente esparsas.

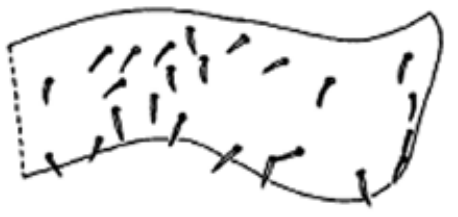

Cabeça, tórax e pernas de cor uniforme ou escura com anelações claras, porém nunca mosqueados; cerdas de urotergitos, na maioria dos casos, dispostas em duas fileiras transversais.

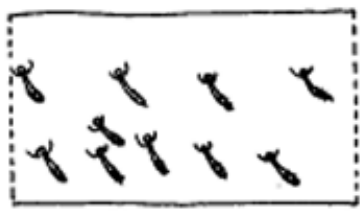


4. Cabeça alongada, cônica; comprimento da região anteocular com cerca do dobro da largura; rostro delgado Rhodnius
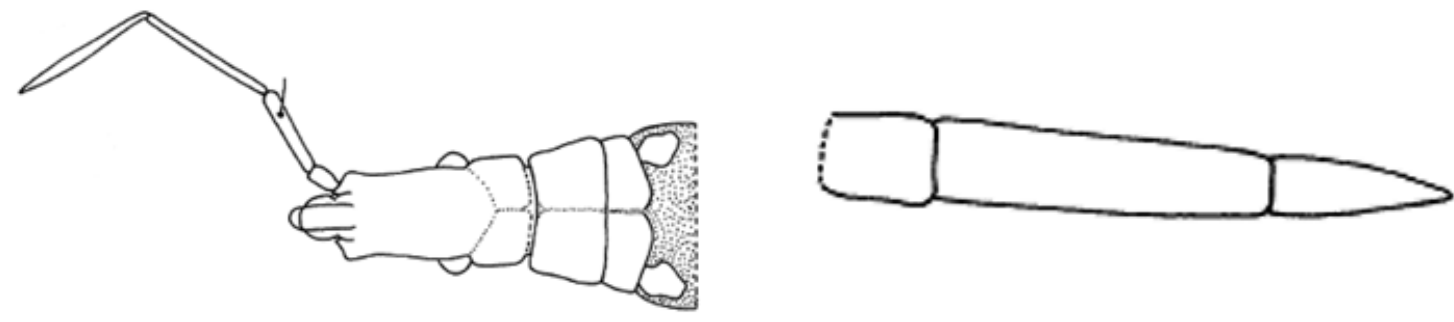

Cabeça curta e larga, região anteocular aproximadamente tão longa quanto larga; rostro robusto. Psammolestes

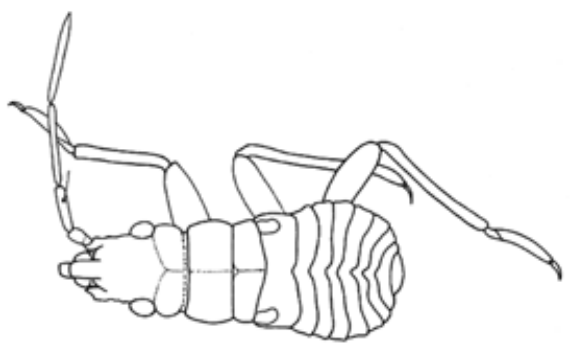

5. Rostro abreviado, não atingindo o prosterno; gênero não encontrado nas Américas Linshcosteus

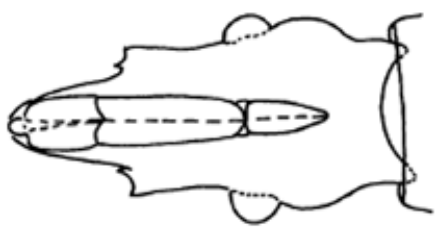

Rostro de comprimento normal, atingindo o prosterno 6

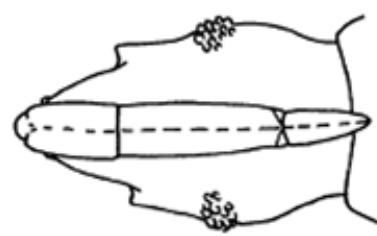

6. Pelos do corpo e apêndices muito longos, eretos ou decumbentes; ápice do segmento distal do tarso posterior sem pelos especializados Paratriatoma
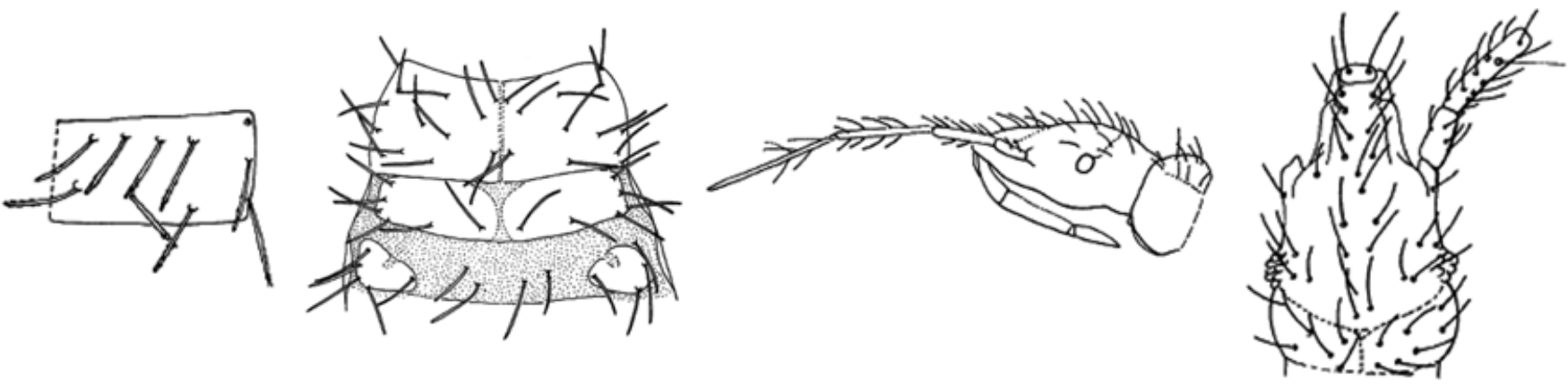
Pelos do corpo e apêndices sempre mais curtos; ápice do segmento distal do tarso posterior com ou sem pelos especializados
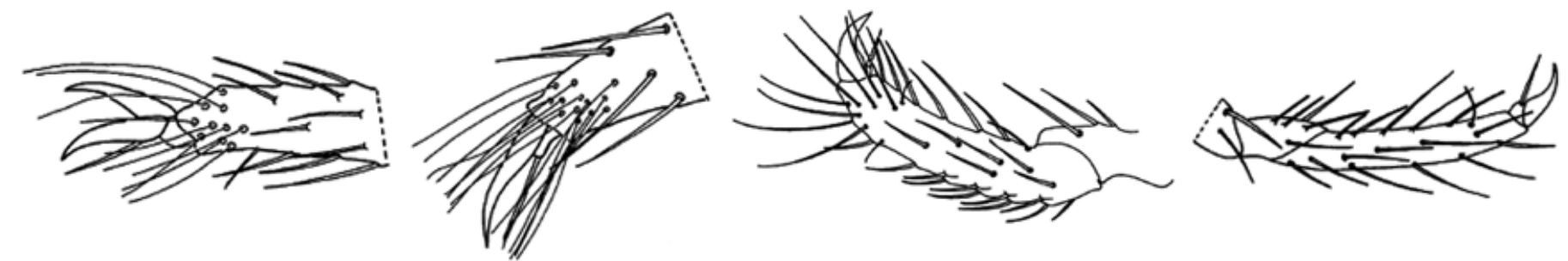

7. Tarso posterior sem pelos sensoriais especializados

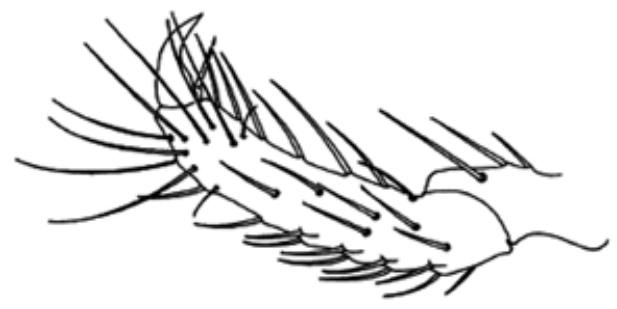

Tarso posterior com pelos sensoriais especializados
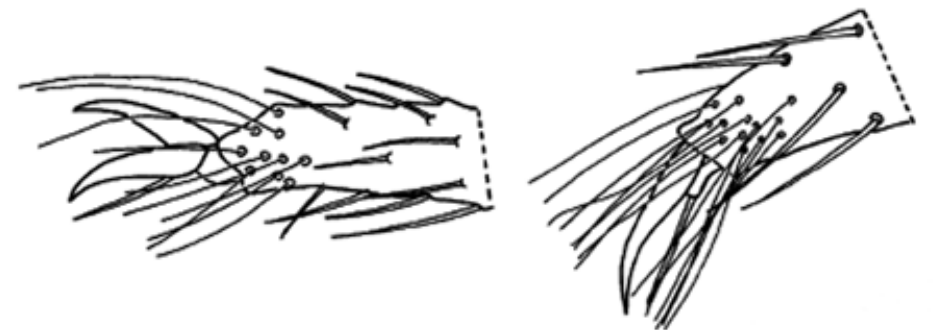

8. Cabeça muito curta, não mais longa que larga de lado a lado dos olhos

Alberprosenia

Cabeça mais longa que larga 9
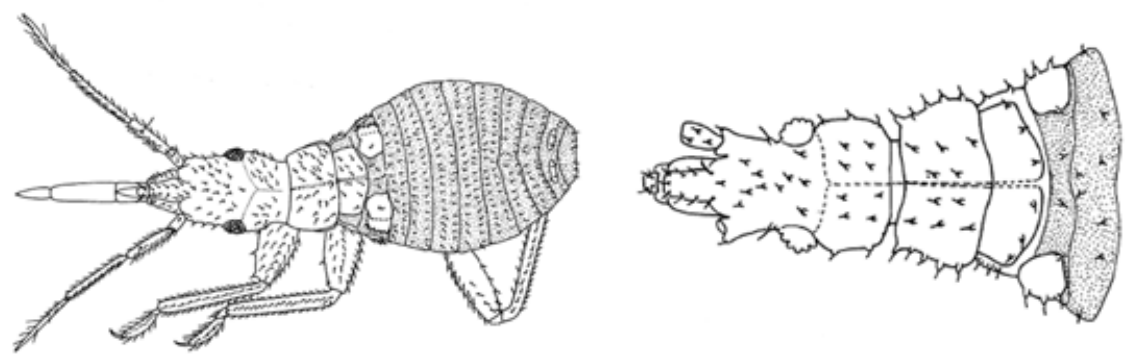

9. Face inferior dos fêmures com dentículos setíferos conspícuos; região pós-ocular da cabeça de lados paralelos e abruptamente constrita antes do pescoço Belminus

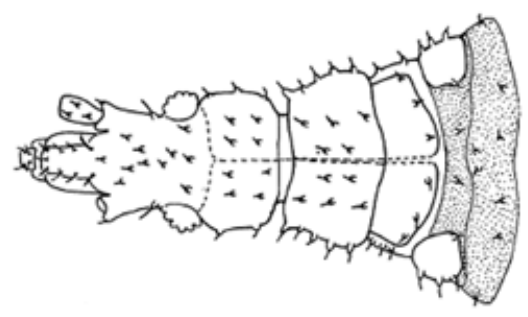


Face inferior dos fêmures com tubérculos setíferos semelhantes aos demais; lados da região pós-ocular de cabeça arredondados e convergindo, gradativamente para o pescoço Triatoma (parte)

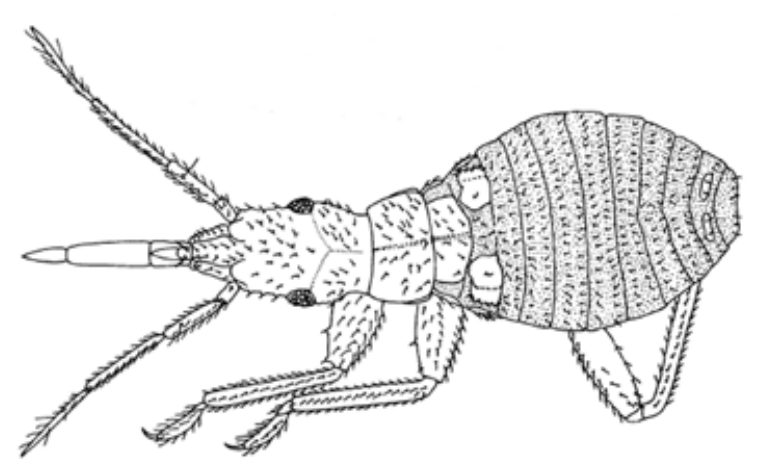

10. Rostro robusto ou delgado; se delgado, o primeiro segmento menor do que a metade do segundo .... 11

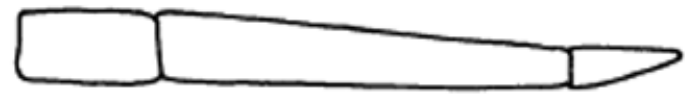

Rostro delgado, o primeiro segmento tendo mais do que a metade do segundo

Eratyrus

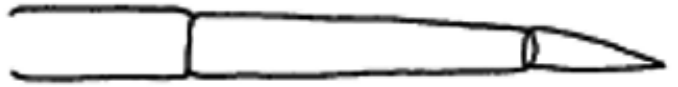

11. Terceiro segmento do rostro com um órgão rostral par; comprimento maior que $6 \mathrm{~mm}$ Dipetalogaster

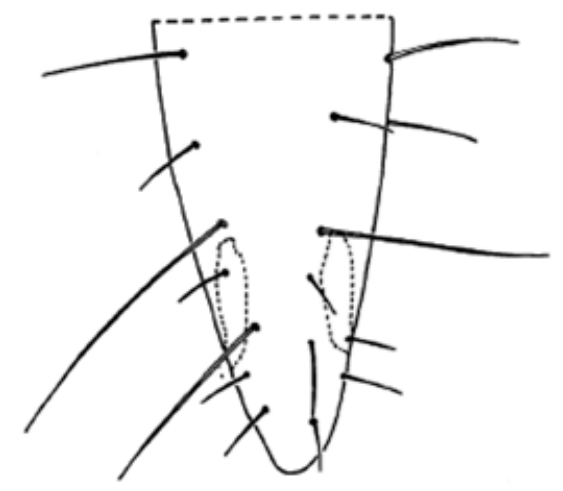

Terceiro segmento do rostro com órgão rostral par ausente; comprimento menor que $6 \mathrm{~mm}$... Panstrongylus, Triatoma (parte) 


\section{Chave para os gêneros de triatomíneos baseada em ninfas de quinto estádio (segundo Lent \& Wygodzinsky, 1979).}

1. Corpo e apêndices com numerosos pelos muito longos, eretos ou decumbentes; cabeça fortemente convexa dorsalmente; tubérculos anteníferos sem processo apical lateral; abdômen sem série de tubérculos no centro dos urotergitos 2
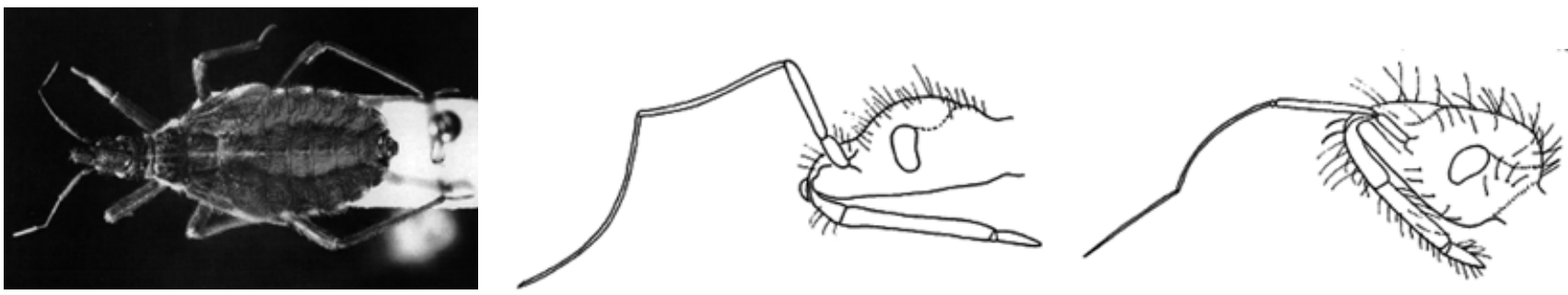

Corpo e apêndices sem pelos muito longos, eretos ou decumbentes; cabeça fortemente convexa no dorso só em poucos casos; tubérculos anteníferos com ou sem processo apical lateral; abdômen com ou sem série de tubérculos no meio dos urotergitos.

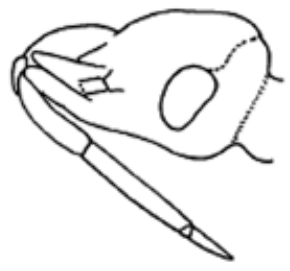

2. Todas os pelos simples; olhos situados no meio da cabeça, lateralmente; quarto artículo antenal mais longo que qualquer outro artículo; terceiro e quarto artículos antenais com anelações microscópicas; sulco estridulatório ausente; tarsos alongados, o anterior com cerca da metade do comprimento da tíbia Cavernicola

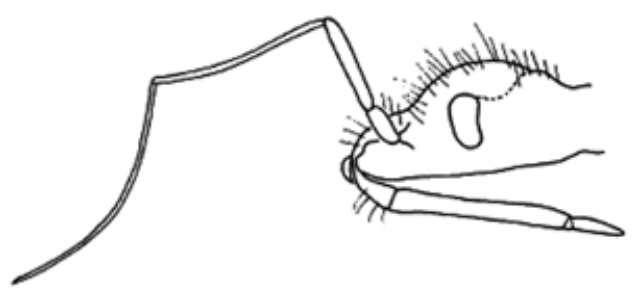

Cerdas espinhosas; olhos situados atrás do meio da cabeça, lateralmente, quarto artículo antenal subigual no comprimento ao segundo ou terceiro; somente o quarto artículo antenal com anelações microscópicas; sulco estridulatório presente; tarsos não alongados, o tarso anterior mais curto que a metade do comprimento da tíbia.
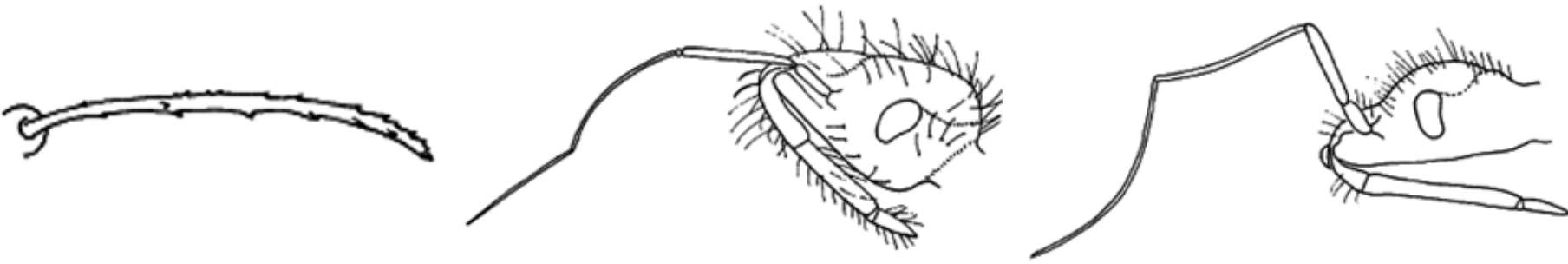
3. Pernas relativamente longas e finas, os fêmures posteriores mais de oito vezes mais longos que largos; primeiro segmento do rostro com duas vezes o comprimento do último

Panstongylus (parte)

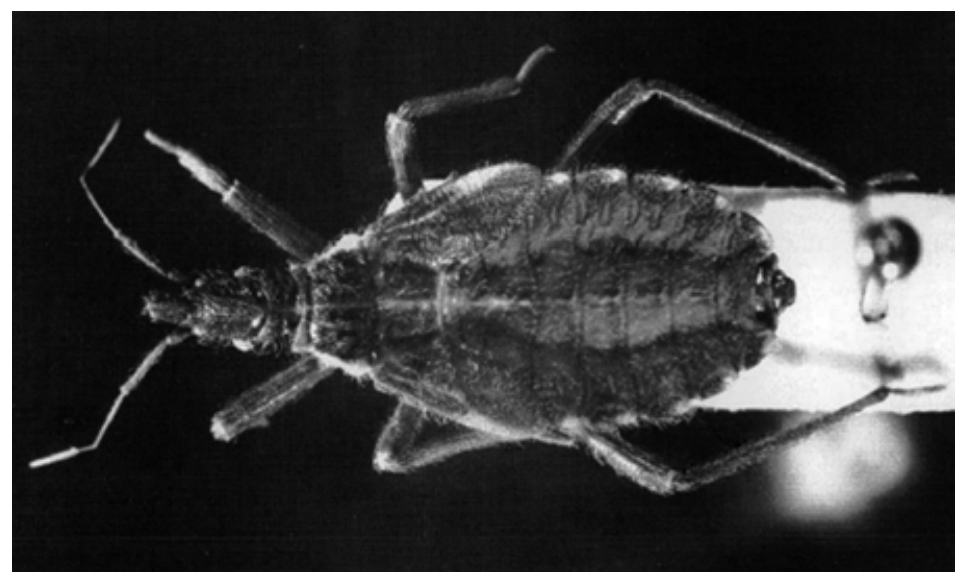

Pernas curtas e robustas, os fêmures posteriores menos de seis vezes mais longos que largos; primeiro segmento do rostro com menos duas vezes o comprimento do último(1:0,7).

Paratriatoma

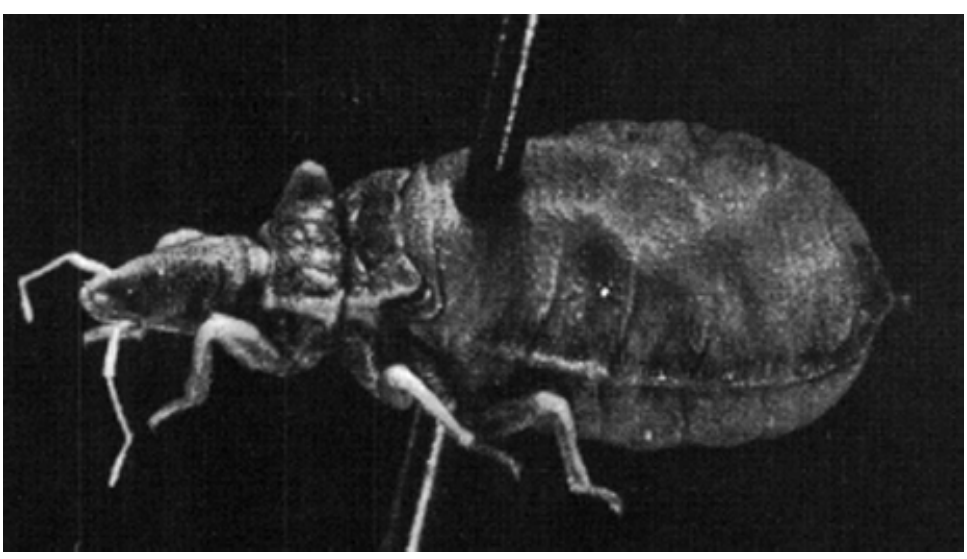

4. Genas muito salientes, projetadas para adiante do nível do ápice do clípeo a uma distância igual à largura do clípeo no ápice; tubérculos anteníferos com processo lateral apical conspícuo; abdômen sem série de grandes tubérculos ao longo da linha mediana dorsal.
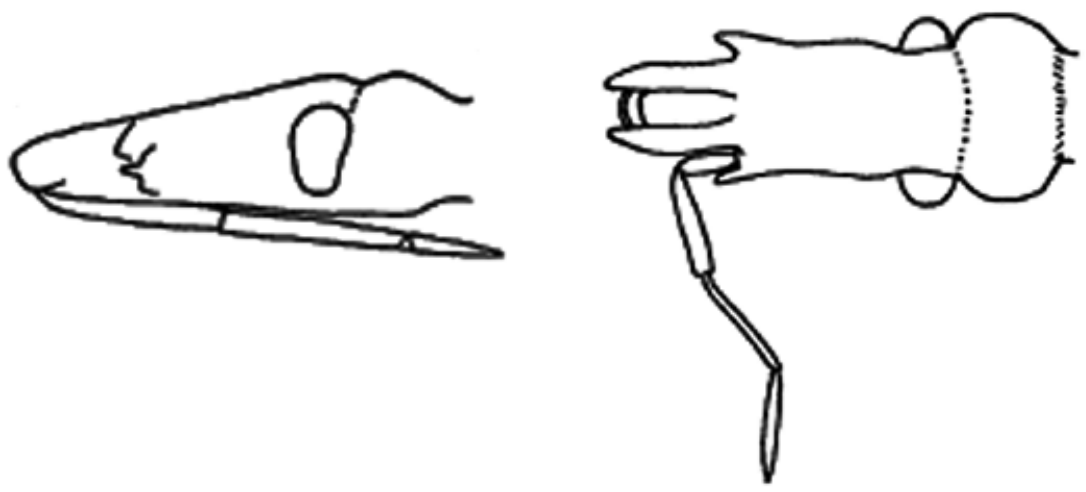
Genas não ultrapassando ou somente apenas ultrapassando o nível do ápice do clípeo; tubérculos anteníferos com ou sem processo apical lateral conspícuo; abdome, com ou sem série de quatro ou cinco tubérculos ao longo da linha mediana dorsal. 8
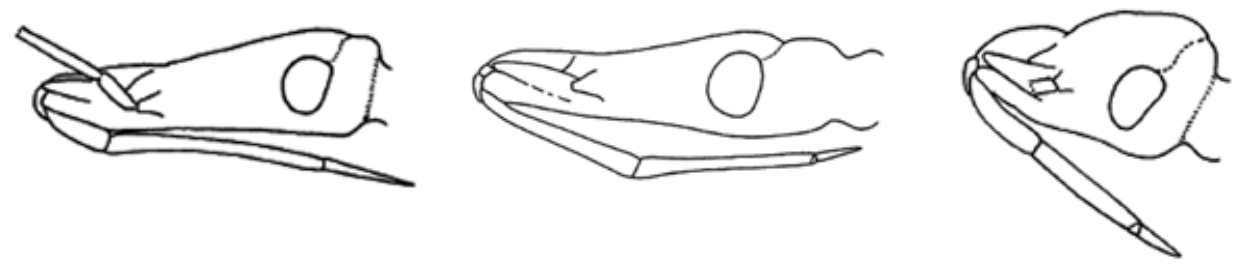

5. Fêmures sem espinhos ou dentículos na face inferior; fosseta esponjosa presente nas tíbias de todos os pares de pernas; tórax não granuloso, com numerosas cerdas curtas escamosas. Microtriatoma

Fêmures com processos espiniformes conspícuos na face inferior; tíbias com ou sem fosseta esponjosa; tegumento dorsal fortemente granuloso

6. Primeiro e segundo segmentos do rostro de comprimento subigual; tíbias sem fosseta esponjosa Belminus

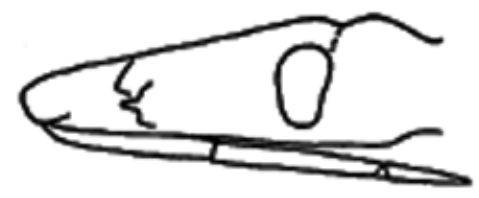

Primeiro segmento do rostro muito menor que o segundo; fossetas esponjosas ausentes ou presentes.

7. Genas espiniformes; fossetas esponjosas ausentes; tarsos alongados, várias vezes mais longos que o diâmetro apical da tíbia Bolbodera Genas lameliformes, achatadas lateralmente, ápice arredondado quando visto de lado; fosseta esponjosa presentes em todas as pernas; tarsos muito curtos, aproximadamente tão longos quanto o diâmetro apical da tíbia

Parabelminus

8. Comprimento até $5 \mathrm{~mm}$; colorido geral píceo ou preto, cabeça delicadamente granulosa, curta e muito larga, não mais comprida que larga de lado a lado dos olhos; terceiro segmento do rostro somente com a metade do comprimento do primeiro; fêmures fusiformes, não achatados lateralmente Alberprosenia Comprimento superior a $5 \mathrm{~mm}$, cabeça mais longa que larga de lado a lado dos olhos; caracteres restantes variados

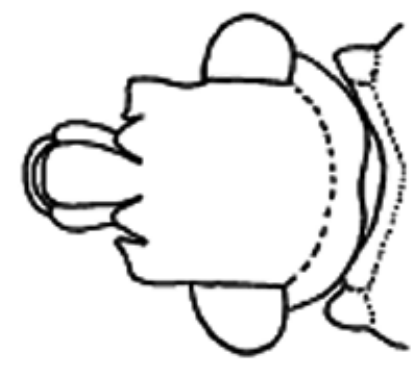


9. Cabeça, curta e larga, lisa; calosidades laterais pós-oculares muito salientes, cerca de quatro quintos da largura do olho; sulco estridulatório tendo de comprimento menos do dobro de sua largura; rostro fortemente achatado dorsoventralmente; pronoto liso; fêmures alargados, achatados lateralmente; abdômen granuloso, mas sem grandes tubérculos ao longo da linha mediana dorsal

Psammolestes

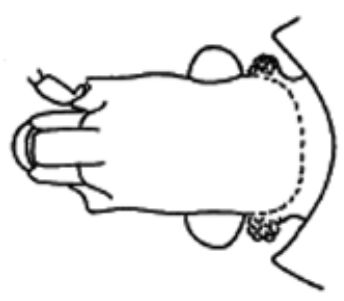

Cabeça diferente; calosidade lateral pós-ocular saliente ausente; sulco estridulatório, quando presente, tendo de comprimento mais do dobro da largura; caracteres restantes variados......10

10. Cabeça alongada, tubérculos anteníferos situados no terço ou quarto anterior da região anteocular; abdômen granuloso no dorso, mas sem a fileira de tubérculos medianos

Rhodnius

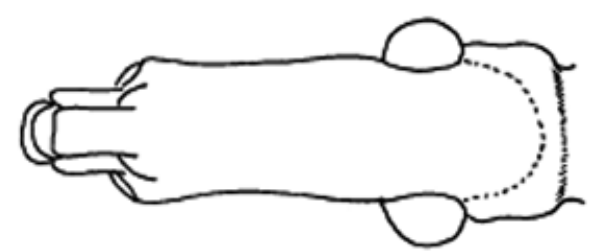

Cabeça alongada ou curta; tubérculos anteníferos situados atrás do quarto anterior da região anteocular; abdômen com ou sem série de tubérculos medianos dorsais
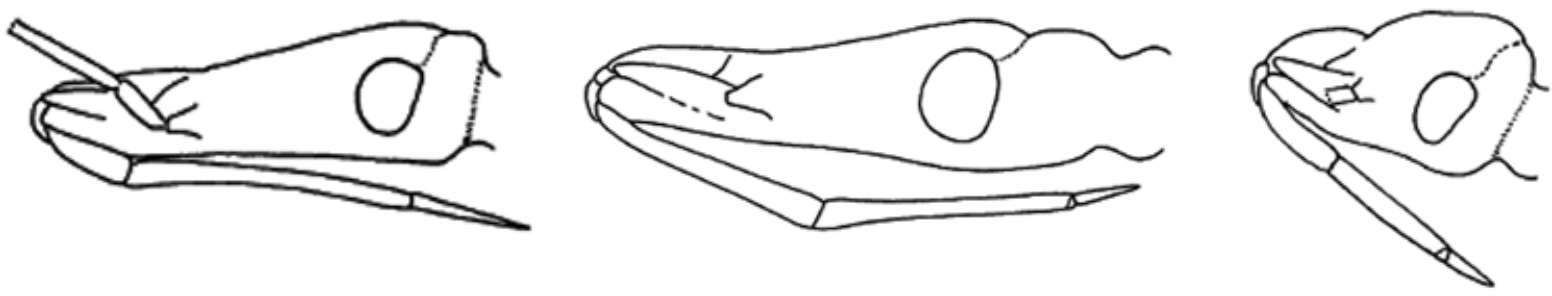

11. Rostro abreviado, não se estendendo para trás do nível dos olhos; sulco estridulatório não desenvolvido. Linshcosteus Rostro de comprimento normal, atingindo prosterno; sulco estridulatório presente.

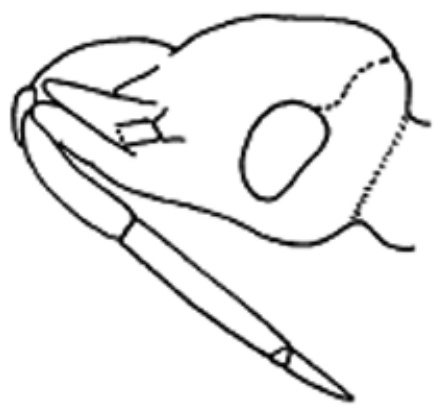


12. Rostro com primeiro e segundo segmentos alongados, de comprimento subigual, o terceiro curto; abdome com uma série de cinco tubérculos medianos dorsais salientes Eratyrus

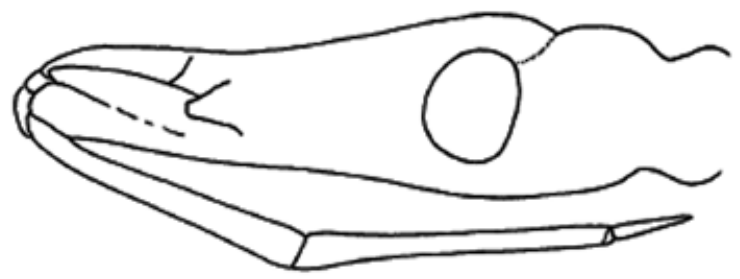

Rostro com o primeiro segmento invariavelmente menor que o segundo; abdômen com ou sem série de tubérculos medianos dorsais.
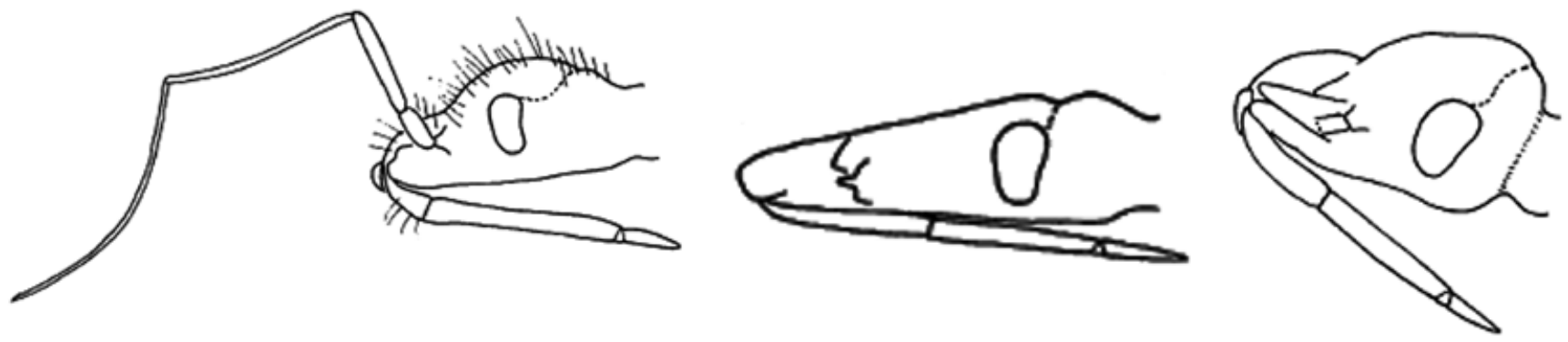

13. Cabeça curta, larga; tubérculos anteníferos situados atrás do meio da região anteocular. Panstrongylus (parte)

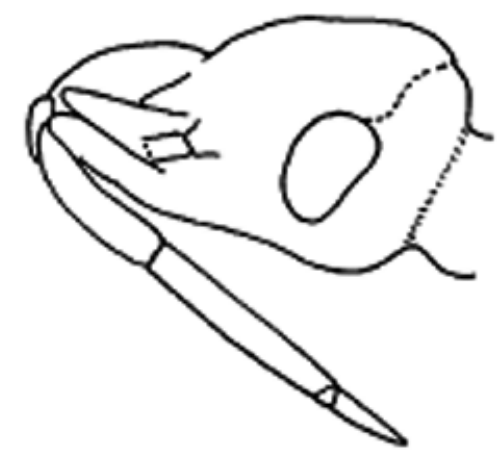

Cabeça longa e estreita; tubérculos anteníferos situados ao nível do meio da região anteocular ou adiante dele

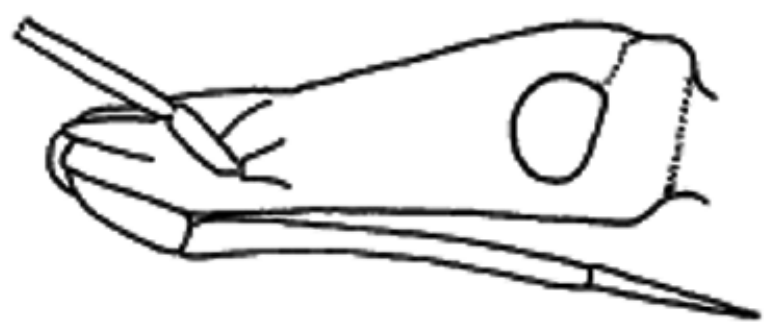


14. Genas pontudas, ultrapassando nitidamente o nível do ápice do clípeo); terceiro e quarto artículos antenais minuciosamente anelado; abdômen, no dorso, sem séries de tubérculos medianos; tamanho superior a $25 \mathrm{~mm}$ Dipetalogaster

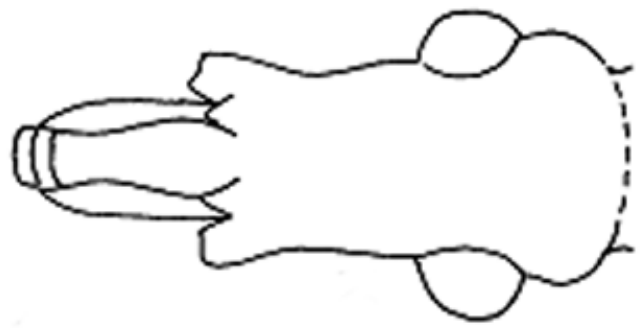

Genas afiladas ou arredondadas apicalmente, não ultrapassando ou só ligeiramente ultrapassando o ápice do clípeo; apenas o quarto artículo antenal anelado; abdômen com ou sem séries de tubérculos medianos no dorso, tamanho $25 \mathrm{~mm}$ ou menos Triatoma

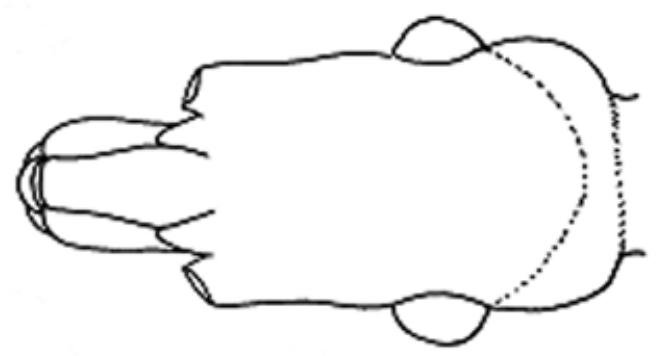




\section{Chave para identificação de 13 espécies do gênero Rhodnius, baseada em características do exocório e dos opérculos dos ovos, e destinada à utilização em microscopia ótica (segundo Santos et al. 2009).}

1. Ovos com cascas de tonalidade branca ou esbranquiçada

Ovos com cascas de tonalidade castanha

2. Ovos com colarinho

Ovos sem colarinho

3. Opérculo de coloração castanho escura; linhas limitantes (LL) lisas, estreitas, retilíneas e pouco refringentes

Opérculo de coloração castanho pálida; linhas imitantes pouco evidentes, rugosas, largas, irregulares e sem refringência; granulações graúdas, abundantes e revestindo uniformemente o tegumento, inclusive as linhas limitantes.

5

4. Funis muito rasos com bordas arredondadas, em corte histológico, sem nenhuma evidência de demarcação das linhas limitantes; linhas limitantes debilmente evidenciáveis e não salientes; granulações irregulares com predomínio de graúdas e distribuição também irregular sobre o tegumento.

Rhodnius nasutus

Funis com bordas levemente pontiagudas, em corte histológico, com fraca evidência de demarcação das linhas limitantes; linhas limitantes frequentemente evidenciáveis, lisas, estreitas, retilíneas e pouco refringentes; granulações miúdas com distribuição uniforme sobre o tegumento. Rhodnius neglectus

5. Ovos atarracados; colo curto e largo; colarinho com expansões que encobrem o colo.

Rhodnius milesi

Ovos alongados; colo longo e estreito.

Rhodnius neivai

6. Funis profundos, com aspecto característico de "favos de colmeia"; linhas limitantes refringentes e de fácil visualização; granulações de fácil observação, frequentemente graúdas, abundantes e mais concentradas na área das linhas limitantes.

Funis rasos, sem o aspecto nítido de "favos de colmeia"; linhas limitantes pouco refringentes e consequentemente de difícil visualização; granulações de difícil observação, miúdas ou irregulares; ovos alongados e colo aparentemente estreito.

7. Funis com bordas pontiagudas e culminadas por proeminência do traçado das linhas limitantes; tubos foliculares frequentemente curtos, com largura irregular, retilíneos ou encurvados e com dilatação apical; ovos alongados e com colo aparentemente normal. Rhodnius prolixus

Funis com bordas arredondadas e lisas, isto é, sem proeminência do traçado das linhas limitantes; tubos foliculares longos e finos com discretas curvaturas e dilatação apical; ovos atarracados e com colo aparentemente largo Rhodnius robustus 
8. Bordas dos funis arredondadas, em corte histológico, culminadas por pequenas proeminências biseladas relativas aos traçados das linhas limitantes; granulações irregulares e com distribuição também irregular; tubos foliculares em corte, longos e com acentuada dilatação apical

Rhodnius domesticus

Bordas dos funis arredondadas, em corte histológico, culminadas por largas proeminências abauladas relativas ao traçado das linhas limitantes; granulações miúdas, esparsas e frequentemente mais concentradas na área das linhas limitantes; tubos foliculares, curtos, largos e com discreta dilatação apical Rhodnius ecuadoriensis (ovos "albinos")

9. Ovos com cascas mais fortemente pigmentadas nas áreas do opérculo, do colarinho e/ou da chanfradura longitudinal 10

Ovos com cascas com coloração homogênea nessas áreas 11

10. Ovos com leve brilho dourado; ausência de colarinho e de chanfradura longitudinal; opérculo e anel situado na área do colarinho com pigmentação em castanho mais escuro 12 Presença de colarinho, embora com expansões discretas; opérculo, colarinho e chanfradura longitudinal com pigmentação castanho escura Rhodnius pallescens

11. Ovos com colarinho 13

Ovos sem colarinho, colo estreito; exocório com aspecto uniforme e limpo, mesmo quando observado através de lupa estereoscópica; linhas limitantes de fácil visualização, largas, lisas, retilíneas e muito refringentes 14

12. Ovos de coloração castanho amarelado; borda corial sem anel de pigmentação mais escura .. Rhodnius colombiensis

Ovos de coloração castanho pálido; borda corial com um anel de pigmentação mais escura ..... Rhodnius ecuadoriensis

13. Ovos com coloração castanho muito pálida e discreto brilho bronzeado; colarinho com expansões discretas; vos alongados e de conformação bem definida; exocório com aspecto uniforme e "limpo", mesmo quando observado na lupa; linhas limitantes de difícil visualização, estreitas, lisas, retilíneas e sem refringência, quando visíveis Rhodnius pallescens (ovos "albinos") Ovos de coloração castanho mais forte e sem brilho; colarinho com expansões acentuadas, praticamente encobrindo o colo; ovos atarracados e de conformação mal definida.; exocório com aspecto irregular e "sujo", mesmo quando observado na lupa; linhas limitantes de fácil visualização, largas, lisas, retilíneas e muito refringentes Rhodnius paraensis

14. Ovos de coloração castanho bronze, discreto brilho áureo; acentuada inclinação do opérculo em relação ao achatamento lateral Rhodnius pictipes Ovos de coloração castanho dourado; cascas com as laterais mais arredondados ou ovos mais abaulados; discreta inclinação em relação ao achatamento lateral Rhodnius stali 
Chave para ovos de algumas espécies brasileiras do complexo Triatoma oliveirai [Estas chaves não incluem todas as nove espécies do complexo porque espécimes ou descrições adequadas não estavam disponíveis (segundo Rocha et al. 2009)]

1. Cório com células pentagonais, hexagonais e poucas heptagonais........................................... baratai

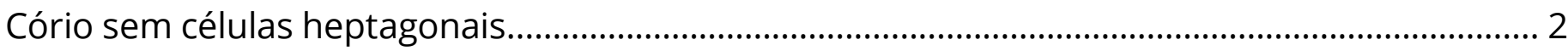

2. Cório com células pentagonais, hexagonais e quadrangulares................................................... oliveirai

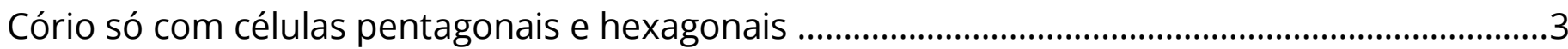

3. Cório com pequenas ranhuras, sem pontos................................................................................. jurbergi

Cório sem pequenas ranhuras, com pontos................................................................................ guazu

Chave para ninfas de primeiro e segundos estádios de algumas espécies brasileiras do complexo Triatoma oliveirai [Estas chaves não incluem todas as nove espécies do complexo pela falta de espécimes ou descrições adequadas (segundo Rocha et al. 2009)]

1. Tubérculos setíferos do tubérculo antenífero com projeção; projeção do pronoto aguçada e com tubérculo T. baratai Sem projeções no tubérculo antenífero, projeção do pronoto romba e sem tubérculo.

2. Espiráculos visíveis

T. oliveirai

Espiráculos não visíveis T. jurbergi, T. guazu

Chave para ninfas de terceiro estádio de algumas espécies brasileiras do complexo Triatoma oliveirai. [Estas chaves não incluem todas as nove espécies do complexo pela falta de espécimes ou descrições adequadas (segundo Rocha et al. 2009)]

1. artículo antenal $2=3$. T. vandae artículo antenal $2<3$. 2 artículo antenal 2>3.

2. 1+1 áreas glabras sublaterais nos tergitos abdominais II, IV, VII

T. guazu 1+1 áreas glabras sublaterais nos tergitos abdominais II, III, IV .T. jurbergi

3. 1+1 áreas glabras sublaterais nos tergitos abdominais III-VII. T. baratai $3+3$ áreas glabras sublaterais nos tergitos abdominais III-VII T. oliveirai 
Chave para as ninfas de quarto estádio de algumas espécies brasileiras do complexo Triatoma oliveirai. [Estas chaves não incluem todas as nove espécies do complexo pela falta de espécimes ou descrições adequadas (segundo Rocha et al. 2009)]

1. artículo antenal $2>3$ 2 artículo antenal $2 \leq 3 \leq 4$ T. jurbergi

2. artículo antenal $3=4$ 3 artículo antenal 3>4 T. vandae, T. williami artículo antenal $3<4$ T. baratai

3. Segmentos torácicos delineadas por cor pálida..... T. guazu Segmentos torácicos com áreas pálidas, mas não tão delineadas T. matogrossensis

Chave para ninfas de quinto estádio de algumas espécies brasileiras do complexo Triatoma oliveirai. [Estas chaves não incluem todas as nove espécies do complexo pela falta de espécimes ou descrições adequadas (segundo Rocha et al. 2009)]

1. Artículo antenal $3=4$ T. williami Artículo antenal $3<4$ T. baratai Artículo antenal 3>4 T. vandae ou 2

2. Segmentos torácicos delineadas por cor pálida T. guazu Segmentos torácicos com áreas pálidas, mas não tão delineadas ..T .matogrossensis, T. jurbergi 